\title{
Chapter 6 \\ Implementation of National Approaches \\ to Circular Migration: Entry and Re-entry \\ Conditions for Migrant Workers \\ in Bulgaria and Poland
}

This chapter brings together the EU and national instruments conducive to circular migration developed in Bulgaria and Poland and assesses their implementation against the backdrop of the study's benchmarks concerning entry and re-entry conditions for migrant workers. ${ }^{1}$ In order to do that, the chapter first presents the national general admission frameworks and the specific instruments identified as favourable to circular migration; as a second step, it focuses on the implementation of EU instruments in the national laws of Bulgaria and Poland. This analysis is complemented by insights into the implementation dynamics of the EU and national instruments on the basis of data collected through focus groups with migrants from Ukraine and Russia as well as interviews conducted with stakeholders and data on permits retrieved from the national administrations of both countries. The chapter ends with an assessment of whether the instruments developed provide options for facilitated entry for migrants from the Eastern partnership countries and Russia, as well as for circulation-friendly policies - for instance, the possibility to grant priority to seasonal workers who have been employed in the territory of a Member State for a significant period over other workers who seek admission to that State.

\footnotetext{
${ }^{1}$ In line with the benchmark framework of the study. See Chaps. 1 and. 4, Sect. 4.2 and Annex V for more details. Parts of this chapter were previously published in Vankova (2017).
} 


\subsection{Entry and Re-entry Conditions According to National Instruments in Poland and Bulgaria}

\subsubsection{General Admission Frameworks}

The Polish Act on Foreigners of $2013^{2}$ regulates the granting, extension, and revocation or cancellation of visas, ${ }^{3}$ including Schengen visas (type C), that permit its holder to remain in the territory of Poland for a maximum of 90 days during a 180day period, ${ }^{4}$ and national long-stay visas (type D). A national visa authorises foreigners ${ }^{5}$ to enter Poland and stay in its territory uninterruptedly or within several consecutive stays lasting, in total, more than 90 days within the period of the visa's validity. ${ }^{6}$ The validity of the visa is not longer than 1 year $^{7}$ and the periods of stay are determined according to the purpose of the stay as specified by the applicant. ${ }^{8}$ Article 60 (1) of the Polish Act on Foreigners lists 30 purposes for which a Schengen or a national visa may be issued, including 'performing work, for a period not exceeding 6 months in the next 12 months, based on declaration entered in the register on commissioning work to a foreigner' referred in the text as the Oświadczenie procedure,,${ }^{9}$ 'carrying out scientific research or development work', ${ }^{10}$ or 'enjoying the rights of a holder of Pole's Card'. ${ }^{11}$ Furthermore, in a flexible manner, the Act allows a foreigner to provide another reason for arriving in Poland that is not indicated in the Act. ${ }^{12}$

In line with Poland's policy towards its eastern neighbours, citizens of three countries are exempt from paying the consular fees for processing visa applications when applying for a Polish national visa. The citizens of Belarus have been exempted from visa application fees since January 2011 after a unilateral decision taken by the Polish Minister of Foreign Affairs. ${ }^{13}$ Before that, the citizens of Belarus had to pay

\footnotetext{
${ }^{2}$ Polish Act on Foreigners of 2013/ Ustawa o cudzoziemcach z dnia 12 grudnia 2013 (Dziennik Ustaw z 2018r., poz. 2094, consolidated text).

${ }^{3}$ See Section IV. For more details, see Kozak et al. (2014), p. 132.

${ }^{4}$ See Article 3 (22) AF.

${ }^{5}$ In this book 'foreigner' and 'third-country national' are used as interchangeable terms. In Polish and Bulgarian legislation 'foreigner' refers to a person who does not have the country's citizenship and excludes EU citizens and members of their families. For more details, see Articles 2 and 3 (2) of the Polish AF and Article 2 of the Bulgarian AFRB.

${ }^{6}$ Article 59 (1) AF.

${ }^{7}$ Article 59 (3) AF.

${ }^{8}$ Article 59 (2) AF.

${ }^{9}$ Article 60 (1) 5 AF.

${ }^{10}$ Article 60 (1) $13 \mathrm{AF}$.

${ }^{11}$ Article 60 (1) $20 \mathrm{AF}$.

${ }^{12}$ Article 60 (1) 25 AF. For more details, see Kozak et al. (2014), p. 132.

${ }^{13}$ European Migration Network (2012), p. 17. In line with the Act of the Minister of Foreign Affairs of the Republic of Poland from 22 December 2015, concerning the reduction of consular fees for
} 
a fee of 20 EUR. Following the adoption of a bilateral intergovernmental agreement, citizens of Ukraine have also been exempted since August 2012 on the basis of the principle of reciprocity. ${ }^{14} \mathrm{~A}$ similar decision was also taken regarding the citizens of Moldova, who as of 1 May 2013 are also exempt from paying the visa processing fees. In addition, foreigners who have obtained the Pole's Card are entitled to receive, free of charge, a special long-stay visa for multiple crossings of the Polish border, issued under Article 60 (1) 20 of the Act on Foreigners. ${ }^{15}$

The Polish Act on Foreigners stipulates that a foreigner is obliged to either leave the territory of Poland or apply for a residence permit within the period of validity of the national visa. ${ }^{16}$ However, Article 82 also lists certain conditions that may lead to the extension of the visa's validity. The most relevant condition for circular migration purposes is that the extension is justified by 'vital personal or professional interests of the foreigner' or when 'the foreigner is unable to leave the territory before the expiry of the national visa or before the end of the authorised period of stay'. ${ }^{17}$ The other conditions are related to unforeseeable events that occur independently of the will of the foreigner at the time of the visa application, when there are circumstances that do not indicate that the purpose of the foreigner's stay will be different than the one declared, and, finally, when there are no grounds on which the foreigner should be refused a visa. ${ }^{18}$

When foreigners apply for a work visa based on Article 60 (1) 4-6 of the Act on Foreigners, they need to either obtain a work permit or have a written declaration of commissioning work to a foreigner in line with the Oświadczenie procedure. ${ }^{19}$ The application and issue of a work permit is regulated by the Act of 20 April 2004 on Employment Promotion and Labour Market Institutions and its implementing regulations. ${ }^{20}$ Article 88 (1) of that Act lists all the cases when an employer needs to

citizens of the Republic of Belarus who apply for a national visa in Belarus, the processing fee for a national visa application has been waived through 31 December 2020.

${ }^{14}$ National Contact Point to the European Migration Network (2013).

${ }^{15}$ For more details see Chap. 5, Sect. 5.2.1.2.

${ }^{16}$ It is beyond this study's scope to discuss refusal to issue visa in details. For more information on this see Kozak et al. (2014), pp. 135-137.

${ }^{17}$ Article 82 (1) 1 AF.

${ }^{18}$ Article 82 (1) 2-4 AF.

${ }^{19}$ Unterschütz (2016), p. 163. It must be stressed that Article 60 (1) 4 focuses on entrepreneurs who require different documents than a work permit or declaration in line with the Oświadczenie procedure as they register and run companies; thus, they would need a work permit only in limited cases.

${ }^{20}$ Act of 20 April 2004 on Employment Promotion and Labour Market Institutions/ Ustawa o promocji zatrudnienia i instytucjach rynku pracy (Dziennik Ustaw z 2019 r., poz. 1482, consolidated text). In addition, as of September 2019 there are five main Regulations that need to be considered: Regulation of the Minister of Family, Labor and Social Policy of 8 December 2018 regarding activity subclasses according to the Polish Classification of Activities (PKD), in which seasonal work permits for a foreigner are issued/Rozporządzenie Ministra Rodziny, Pracy i Polityki Społecznej z dnia 7 września 2018 r. zmieniające rozporządzenie w sprawie podklas działalności według Polskiej Klasyfikacji Działalności (PKD), w których wydawane są zezwolenia na pracę 
apply for a work permit. ${ }^{21}$ When a foreigner carries out work in Poland under an employment or civil law contract with an employer whose seat or residence is in the territory of Poland, a work permit is issued by the governor (wojewoda) of the province (województwo), if the remuneration offered to the migrant worker is not lower than the remuneration of Polish employees performing work of a comparable type or comparable work, and if the results of a labour market test are negative. ${ }^{22}$

According to Polish law, a labour market test is performed by the Local Labour Office (Powiatowy Urzad Pracy) on behalf of the local governor (starosta) upon a notification of a vacancy by the employer ${ }^{23}$ The competent Local Labour Office, depending on the place where the work will be performed, issues a decision about either the lack of possibilities to meet the workforce needs of the employer on the basis of a review of the register of the unemployed and job-seekers (within 14 days from the date of submitting the vacancy to the Labour Office) or about possible recruitment among those registered at the Labour Office (within 21 days from the date of submitting the vacancy to the Labour Office). The decision issued by the governor is then attached to the work or single permit application. The labour market test also takes into account the priority of access to the labour market for Polish and EU citizens, as well as other categories of foreigners stipulated in Article 87 (1)

sezonową cudzoziemca (Dziennik Ustaw z 2018 r., poz. 1749); Regulation of the Minister of Labor and Social Policy of 29 January 2009 on determining cases in which a work permit for a foreigner is issued regardless of the detailed conditions for issuing work permit for foreigners/ Rozporządzenie Ministra Pracy i Polityki Społecznej z dnia 29 stycznia 2009 r. w sprawie określenia przypadków, w których zezwolenie na pracę cudzoziemca jest wydawane bez względu na szczegółowe warunki wydawania zezwoleń na pracę cudzoziemców (Dziennik Ustaw z 2019 r., poz. 154, consolidated text); Regulation of the Minister of Family, Labor and Social Policy of 8 December 2017 regarding the fees for filing an application for a work permit or seasonal work permit and a declaration of commissioning work to a foreigner/Rozporządzenie Ministra Rodziny, Pracy i Polityki Społecznej z dnia 8 grudnia 2017 r. w sprawie wysokości wpłat dokonywanych w związku ze złożeniem wniosku o wydanie zezwolenia na pracę lub zezwolenia na pracę sezonową oraz złożeniem oświadczenia o powierzeniu wykonywania pracy cudzoziemcowi (Dziennik Ustaw z 2017 r., poz. 2350); Regulation of the Minister of Labour and Social Policy of 8 December 2017 regarding the citizens of countries that are subject to certain provisions concerning a seasonal work permit, as well as provisions concerning the declaration on commissioning work to a foreigner/ Rozporządzenie Ministra Rodziny, Pracy i Polityki Społecznej z dnia 8 grudnia 2017 r. w sprawie państw, do których obywateli stosuje się niektóre przepisy dotyczące zezwolenia na pracę sezonową oraz przepisy dotyczące oświadczenia o powierzeniu wykonywania pracy cudzoziemcowi (Dziennik Ustaw z 2017 r., poz. 2349); Regulation of the Minister of Family, Labor and Social Policy of 7 December 2017 regarding the issue of a work permit for a foreigner and the entry of a declaration on commissioning work to a foreigner in the register of declarations/ Rozporządzenie Ministra Rodziny, Pracy i Polityki Społecznej z dnia 7 grudnia 2017 r. w sprawie wydawania zezwolenia na pracę cudzoziemca oraz wpisu oświadczenia o powierzeniu wykonywania pracy cudzoziemcowi do ewidencji oświadczeń (Dziennik Ustaw z 2017 r., poz. 2345).

${ }^{21}$ For a detailed description of the different work permits, see Unterschütz (2016), 167-168.

${ }^{22} \mathrm{~A}$ labour market test is performed as part of the application procedure for type A work permits. See Article 88c (1) AEPLMI.

${ }^{23}$ See Article 88c (1) 2 AEPLMI. 
of the Act on Employment Promotion and Labour Market Institutions and having the right to work in Poland.

Nonetheless, there are several cases in which specific categories of migrant workers can be exempted from the obligation to perform a labour market test, such as when the job is covered by the list of occupations which are in great demand, as provided for on the national level in a Regulation of the Minister of Labour and Social Policy ${ }^{24}$ or listed in an Ordinance issued by a governor of the province. ${ }^{25}$ In case of a successful application, a work permit is issued for a specified period of time, which cannot be longer than 3 years but which can be extended. ${ }^{26}$ In addition, the Act on Employment Promotion and Labour Market Institutions allows for many exemptions from the requirement to obtain a work permit listed under Article 87 (2). This Article is given further enumeration by a Regulation issued by the Minister of Labour and Social Policy. ${ }^{27}$

In comparison, the Bulgarian Act on Foreigners in the Republic of Bulgaria $(\mathrm{AFRB})^{28}$ establishes the terms and procedures under which foreigners may enter, reside, and leave the Republic of Bulgaria (Article 1 of the AFRB). ${ }^{29}$ As mentioned above, the visas that are relevant to this research are short-stay visas for the purposes of a planned stay on the territory of the Republic of Bulgaria (visa type C) and long-stay visas (visa type D). ${ }^{30}$ Short-stay visas with the purpose of a planned stay must be issued for a period not exceeding 90 days, within any 6-month period, to be counted from the date of first entry into the Republic of Bulgaria (Article 14 (1) of the AFRB).

\footnotetext{
${ }^{24}$ For the most recent list of occupations, see Regulation of the Minister of Family, Labour and Social Policy of 28 June 2018 amending the Regulation on determining cases in which a work permit for a foreigner is issued irrespective of the detailed conditions for issuing work permits for foreigners/ Rozporządzenie Ministra rodziny, pracy i polityki społecznej z dnia 28 czerwca 2018 r. zmieniające rozporządzenie w sprawie określenia przypadków, w których zezwolenie na pracę cudzoziemca jest wydawane bez względu na szczegółowe warunki wydawania zezwoleń na pracę cudzoziemców (Dziennik Ustaw z 2018 r., poz. 1264).

${ }^{25}$ Article 10 (4) 1 AEPMLI.

${ }^{26}$ Article 88e (1) AEPLMI.

${ }^{27}$ Regulation of the Minister of Labour and Social Policy of 21 April 2015, concerning cases when commissioning work to foreigners in the territory of the Republic of Poland is permitted without the requirement of obtaining a work permit/Rozporządzenie Ministra Pracy i Polityki Społecznej w sprawie przypadków, w których powierzenie wykonywania pracy cudzoziemcowi na terytorium Rzeczypospolitej Polskiej jest dopuszczalne bez konieczności uzyskania zezwolenia na pracę. (Dziennik Ustaw z 2018 r., poz. 2273, consolidated text).

28 Закон за чужденците в Република България (SG No. 153/23 December 1998, last amendment SG No. 58/23 July 2019).

${ }^{29}$ Visas are not required in line with Council Regulation (EC) No. 539/2001 of 15 March 2001, other acts of the European Union, international agreements or acts of the Council of Ministers, as well as in cases where the foreigner has a valid permit for continuous, long-term, or permanent residence in Bulgaria (Article 8 (2) and (3) AFRB).

${ }^{30}$ For more details see Article 9a in conjunction with Article 14 AFRB. Transit visas regulating these types of stays fall outside the scope of this study and therefore are not presented in detail.
} 
National long-term visas with a validity of up to 6 months that grant the right to stay in Bulgaria for up to 180 days can be issued when the foreigner intends to apply for continuous, long-term, or permanent residence ${ }^{31}$ on one of the grounds stipulated by the Act (Article 15 (1) of the AFRB). Long-stay visas with a validity of up to 1 year and with right of stay for up to 360 days may be issued to foreigners only in specific cases that are listed in the Regulation on the terms and procedure for issuing visas and for determining the visa regime. ${ }^{32}$ Once a residence permit has been issued, the visa is annulled (Article 15 (4) of the AFRB). ${ }^{33}$

Unlike Poland, Bulgaria's visa policy did not provide any facilitation for Eastern Partnership countries or for Russia until 2018, when Bulgaria signed bilateral labour migration agreements with Armenia and Moldova (discussed in the next section of this chapter). Applicants are still required to pay all the appropriate fees, unless they fall under one of the exemptions contained in the EU visa facilitation agreements. The only other facilitation for nationals of Ukraine and Russia is provided through the outsourced Visa Application Centres operated by the VFS Global Company. ${ }^{34}$ In 2015, several members of the Bulgarian Parliament introduced a draft resolution seeking to abolish visas for Russian citizens - a measure which, in itself, was contrary to EU Visa List Regulation 539/2001. ${ }^{35}$ The Ministries of Interior and Foreign Affairs intimated their positions to the Parliamentary Commission on Economic Policy and Tourism, stressing that facilitations already existed, namely the outsourced Visa Application Centres and the visa-free regime for holders of Schengen visas issued by other Member States.

\footnotetext{
${ }^{31}$ According to Article 23 (2) AFRB, continuous residence means an authorized stay for up to 1 year, except in the cases provided for in the law. Article 24 (1) enumerates the cases when a foreigner can apply for such permit. To obtain a continuous permit, for the period of residence foreigners should have insured accommodation, compulsory health and social security insurance, sufficient means of subsistence without resorting to the social assistance system not less than the minimum monthly salary, minimum stipend, or minimum pension according to the legislation of Bulgaria (Article 24 (2) AFRB).

${ }^{32}$ Наредба за условията и реда за издаване на визи и определяне на визовия режим (adopted by Council of Ministers Decree No 198/ 11 July 2011, SG No. 55/19 July 2011, last amendment SG No. 27/2 April 2019). According to Article 9 (2), these are foreigners who conduct scientific research or who are students on 1-year educational programmes, post-graduate students or trainees, foreigners sent on a business trip by a foreign employer in order to perform specific tasks, related to the control and coordination of fulfilment of a contract for tourist services, as well as to foreigners sent on a business trip by a foreign employer for making and maintaining investments, certified following the procedure laid down in the Investment Promotion Act.

${ }^{33}$ It is beyond the study's scope to discuss refusal to issue visa in details. For more information on this see Article 10 AFRB for full list of the grounds on which visas may be refused.

${ }^{34}$ Visa application centres operate in the following Russian cities: Moscow, Sankt Petersburg, Ekaterininburg, Novosibirsk, Kazan, Samara, Nijni Novgorod, Krasnodar, Krasnoyarsk, Rostov on Don, Vladivostok, Khabarovsk, Irkutsk, Ufa, Sochi and Kaliningrad; and in Kiev, Odessa, Lvov, Lutsk, Ivano-Frankovsk, Donetsk, Kharkov and Simferopol in Ukraine. Source: Ministry of Foreign Affairs (2018).

${ }^{35}$ National Assembly of the Republic of Bulgaria/Народно събрание на Република България/ (2015). For more details on the EU visa policy, see Chap. 4, Sect. 4.2.2.
} 
According to the Act on Labour Migration and Labour Mobility (ALMLM), ${ }^{36}$ the initial application for access to the Bulgarian labour market is only possible when the applicant is outside the territory of Bulgaria (Article 5 (2) of the ALMLM). The authorisation for access to the labour market is subject to the negative results of a labour market test that is to be performed by the employer and proof that in the previous 12 months, the total number of third-country nationals working for the local employer did not exceed $20 \%$ of the average number of workers employed (35\% in the case of medium and small enterprises). ${ }^{37}$ In addition, foreigners also need to be offered working conditions that are no less favourable than the conditions offered Bulgarian citizens in the respective labour category. Finally, the foreign worker must possess specialised knowledge, skills, and professional experience that is required for the post in question (Article 7 (1) of the ALMLM).

The employer carries out the labour market test by publishing a job advert containing information about the requirements for filling the specific position, remuneration, and other social benefits. The job vacancy must be published in media with national coverage, as well as in the Local Labour Office (Бюро по труда) at the prospective place of work of the applicant (Article 4 (1) of the Implementing Regulation of $\mathrm{ALMLM}^{38}$ ). The duration of this labour market test ranges between 15 days and 3 months. The results of the test are used by the Employment Agency in order to establish the 'objective impossibility' of the employer to employ a Bulgarian citizen, a citizen of another EU Member State or country that is party to the Agreement on the European Economic Area or the Swiss Confederation, or any other foreigner legally residing in Bulgaria who has the right to fill the vacant position. ${ }^{39}$

There are several exceptions to the work authorisation procedure that are predominantly based on EU law and applicable to the following types of workers who do not need a work permit in order to work in Bulgaria: ship crew members; workers with long-term and permanent residence permits and their family members; recognised refugees and their family members in line with the Act on Asylum and Refugees; foreigners whose employment is a result of the implementation of an international treaty; family members of Bulgarian and EU citizens; diplomatic mission members and accredited journalists from foreign media outlets; and foreigners pending expulsion after 1 year of the issue of the expulsion order (Article 9 (1) of the ALMLM).

In line with the priorities of the national migration policy, migrants of Bulgarian origin are also entitled to facilitated labour market access without a work permit

\footnotetext{
36 Закон за трудовата миграция и трудовата мобилност (SG No. 33/ 26 April 2016, last amendment No. 34/ 23 April 2019).

${ }^{37}$ According to Article 14 (1) ALMLM, the Minister of Labour and Social Policy, where proven appropriate, may authorise labour market access on a case-by-case basis outside these limitations.

${ }^{38}$ Правилник за прилагане на Закона за трудовата трудовата миграция и трудовата мобилност (SG No. 79/ 7 October 2016, last amendment SG No. 27/ 2 April 2019).

${ }^{39}$ The categories are listed under Article 9 (1) 2-6 ALMLM.
} 
under Article 8 (2) 1 and (3) of the ALMLM. Currently they only need to be registered by the employer in the Employment Agency in line with Article 30a of the Implementing Regulation of the ALMLM. The provisions concerning labour market access of migrants of Bulgarian origin were amended in May 2018 and replaced the former, rather ambiguous, formulation of Article 8 (2) 1 and Article 15 (4) 1 of the ALMLM. ${ }^{40}$ As mentioned in Chap. 5, these foreigners of Bulgarian origin often come from the Eastern Partnership countries and are entitled to facilitated access to naturalisation.

According to Article 7 (4) of the ALMLM, the work permits are issued with a period of validity of 1 year only and the overall duration of the work authorisation can be extended for up to 3 years if circumstances for its issue have not changed (Article 7 (5) of the ALMLM). After this 3-year period has elapsed, foreigners can submit a follow-up application from outside the territory of Bulgaria. Furthermore, according to Article 7 (1) of the Implementing Regulation of the ALMLM, upon reaching the maximum work authorisation period of 3 years under Article 7 (5) of the ALMLM, a new work authorisation application can only be submitted after a 3-month interruption between the expiration of the third-country national's permit and the request for a new starting period of employment.

\subsubsection{National Instruments Conducive to Circular Migration}

One of the categories of foreigners in Poland exempt from the requirement to obtain a work permit are workers admitted on the basis of the Oświadczenie procedure, which has been identified as one of the instruments facilitating circular migration. ${ }^{41}$ This procedure allows employers to recruit foreigners to work in Poland for a period not exceeding 6 months within a 12-month period on the basis of a declaration of commissioning work to a foreigner. Nationals of Armenia, Belarus, Moldova, Russia, Georgia, and Ukraine - in line with the Regulation of the Minister of Labour and Social Policy on the citizens of countries subject to certain provisions concerning a seasonal work permit as well as provisions concerning the declaration on commissioning work to a foreigner on the basis of Article 90 (10) 2 of the Act on Employment Promotion and Labour Market Institutions - are eligible candidates for the Oświadczenie procedure. ${ }^{42}$

The respective Local Labour Office, depending on the employer's office location or place of permanent residence, is required to register declarations of commissioning work to a foreigner only in cases when the following conditions are fulfilled (in

\footnotetext{
${ }^{40}$ See SG No. 24/ 16 March 2018. A new Para 3 was introduced.

${ }^{41}$ On the basis of Article 87 (3) AEPLMI. See Chap. 5, Sect. 5.2.1.1 for more details.

${ }^{42}$ Rozporządzenie Ministra Rodziny, Pracy i Polityki Społecznej z dnia 8 grudnia 2017 r. w sprawie państw, do których obywateli stosuje się niektóre przepisy dotyczące zezwolenia na pracę sezonową oraz przepisy dotyczące oświadczenia o powierzeniu wykonywania pracy cudzoziemcowi (Dziennik Ustaw z 2017 r., poz. 2349).
} 
line with Article 88z (2) of the AEPLMI): applicants are citizens of the abovementioned countries; they are not engaged in the sectors of agriculture or hospitality and catering, which are reserved for holders of EU seasonal work permits; and, the period of work does not exceed 6 months in total within the following 12 months, independent of the number of entities (employers) commissioning a work to foreigners on the basis of such a declaration or declarations already entered in the registry at a respective Local Labour Office.

The Local Labour Office shall enter declarations of commissioning work to a foreigner in the register of declarations or refuse to do so on behalf of the local governor by way of a decision within 7 working days from the date of receipt of the declaration in cases not requiring additional verification..$^{43}$ If such verification is required, this should be done no later than in 30 consecutive days from the date of receipt of the declaration. The employer is obliged to inform the respective authorities whether the foreigner, for whom a declaration has been registered, has started the job in question or not (Article 88z (13) of the AEPLMI). The legal basis for refusing to register a declaration, the possibility to conduct additional verification, and the obligation of the employers to register presence and work of the foreigner were three important amendments introduced with the reform of the Oświadczenie procedure in 2018.

The declaration that the employer needs to submit for registration shall indicate: information concerning the entity commissioning the foreigner to perform a given job; information concerning the worker in question; and, data concerning the job offered to the foreigner. ${ }^{44}$ It also states that the employer is acquainted with the legal regulations on entrusting a job to a foreigner in the territory of the Republic of Poland..$^{45}$ Another requirement is that the declaration needs to indicate the type of contract serving as the basis for performing the said job ${ }^{46}$ as performing work on the basis of the declaration is only legal when, after their entry into Poland, foreigners conclude an employment or service (referred also as 'civil') contract with the employer. ${ }^{47} \mathrm{~A}$ signed and registered declaration can serve as the basis for the work visa application. ${ }^{48}$

The other instrument in Poland identified as circulation-friendly is the Pole's Card. ${ }^{49}$ Foreigners who have obtained a Karta Polaka are also exempted from the requirement to apply for a work permit in line with Article 87 (2) 6 of the Act on Employment Promotion and Labour Market Institutions. This facilitates their access to the Polish labour market.

\footnotetext{
${ }^{43}$ Article $88 z$ (4) AEPLMI. For the grounds of refusal, see Article 88z (5) and (6) AEPLMI.

${ }^{44}$ See Article $88 \mathrm{z}$ (1) AEPLMI for more details.

${ }^{45}$ Article $88 \mathrm{z}$ (1) 1 (h) AEPLMI.

${ }^{46}$ Article $88 z$ (1) 3 (e) AEPLMI.

${ }^{47}$ For more details on the possible financial penalty and Criminal Code regulation penalising untrue statements see Kozak et al. (2014), p. 142.

${ }^{48}$ Kozak et al. (2014), p. 142.

${ }^{49}$ See Chap. 5, Sect. 5.2.1.2 for more details.
} 
As already mentioned in Chap. 5, bilateral labour migration agreements were identified as the main Bulgarian instrument aimed at facilitating circular migration. The agreements concluded between Bulgaria and Armenia ${ }^{50}$ and Bulgaria and Moldova, ${ }^{51}$ respectively, cover citizens of these countries that have concluded labour contracts under these agreements and obtained the necessary residence authorisations for the particular host-country (Article 2 (1) of both Agreements). Migrant workers from Armenia and Moldova can be employed in Bulgaria without a work permit for an initial period of up to 1 year with the possibility of subsequent prolongation for a total of 3 years. Seasonal workers from these countries can work in Bulgaria for the maximum period of 9 months in line with the Seasonal Workers' Directive (Article 2 (1) 6 of both Agreements).

Migrant workers coming to Bulgaria on the basis of these agreements are required to sign a declaration obliging them to return to the territory of their sending state upon expiration of their legal residence and to present their passport personally to its consulate within 1 month of their return (Article 23 of the Agreement of Moldova/ Article 13 of the Agreement with Armenia). Non-fulfilment of this obligation might impact a future application for a residence permit submitted to the Bulgarian authorities. All this shows that the agreements provide for a circular migration model closer to a temporary migration scheme.

In addition, as already mentioned, these agreements provide for visa facilitation measures: 'Visa applications under this agreement shall be processed with priority by the competent consular service of the receiving party on the territory of the sending party, in accordance with the laws of the parties and in accordance with the relevant provisions of the international treaties binding to both parties' (Article 8 (1) of both Agreements). This is a positive development compared, for instance, to the labour migration agreement concluded between Bulgaria and Israel that does not provide for any explicit visa facilitation measures (see Article 7 (2)). ${ }^{52}$

\footnotetext{
${ }^{50}$ Agreement between the Republic of Bulgaria and the Republic of Armenia on labour migration management, approved by Council of Ministers Decision No. 176 of 22 March 2018, entered into force 9 October 2018/Спогодба между Република България и Република Армения за регулиране на трудовата миграция, утвърдена с Решение № 176 от 22 март 2018 г. на Министерския съвет, в сила от 9 октомври 2018 г.

${ }^{51}$ Agreement between the Government of the Republic of Bulgaria and the Government of the Republic of Moldova on labour migration management, approved by Council of Ministers Decision No 492 of 13 July 2018, entered into force on 11 September 2018/Спогодба между правителството на Република България и правителството на Република Молдова за регулиране на трудовата миграция, утвърдена с Решение № 492 на Министерския съвет от 13 юли 2018 г., в сила от 11 септември 2018 г.

${ }^{52}$ Agreement between the Government of the Republic of Bulgaria and the Government of the State of Israel, regarding recruitment and temporary employment of citizens of the two countries, adopted with Council of Ministers Decree No 852/24 November 2011, in force from 20 December 2011/Спогодба между правителството на Република България и правителството на Държавата Израел за посредничество и временна заетост на граждани на двете държави.
} 


\subsection{Entry and Re-entry Conditions Provided by National Instruments - Implementation Dynamics}

Table 6.1 presents the number of declarations of commissioning work to a foreigner by employers since 2009 as part of the Oświadczenie procedure in Poland. It needs to be stressed, however, that this number does not reflect the real number of people who came to Poland with visas issued under these declarations - which was smaller. ${ }^{53}$ The data demonstrate a steady rise in the declarations since 2014 , leading to a peak of 1,824,464 declarations in 2017. The decline since 2018 can be attributed mainly to legal amendments of the Oświadczenie procedure, the transposition of the Seasonal Workers' Directive that came in force in the same year, and the introduction of the visa-free regime with Ukraine (only for biometric passport holders), which is the country of origin of more than $90 \%$ of the declarations. ${ }^{54}$

Even though a larger share of foreigners work on the basis of a registered declaration, ${ }^{55}$ the picture of the migration dynamic in Poland will not be complete without data on the number of work permits issued. This has increased gradually

Table 6.1 Registered declarations under the Oświadczenie procedure in the period 2009 - first half of 2019

\begin{tabular}{|c|c|c|c|c|c|c|c|}
\hline \multirow[b]{2}{*}{ Year } & \multicolumn{6}{|c|}{ Citizenship } & \multirow[b]{2}{*}{ Total per year } \\
\hline & Belarus & Russia & Ukraine & Moldova & Georgia & Armenia & \\
\hline 2009 & 4860 & 674 & 180,133 & 2747 & - & - & 188,414 \\
\hline 2010 & 3623 & 595 & 169,490 & 5912 & 453 & - & 180,073 \\
\hline 2011 & 4370 & 963 & 239,646 & 13,024 & 1774 & - & 259,777 \\
\hline 2012 & 7636 & 1624 & 223,671 & 9421 & 1384 & - & 243,736 \\
\hline 2013 & 5194 & 1260 & 217,571 & 9248 & 2343 & - & 235,616 \\
\hline 2014 & 4017 & 1227 & 372,946 & 6331 & 2103 & 774 & 387,398 \\
\hline 2015 & 5599 & 1939 & 762,700 & 9575 & 1366 & 1043 & 782,222 \\
\hline 2016 & 23,400 & 3937 & $1,262,845$ & 20,650 & 1698 & 1597 & $1,314,127$ \\
\hline 2017 & 58,046 & 6150 & $1,714,891$ & 31,465 & 11,126 & 2786 & $1,824,464$ \\
\hline 2018 & 62,805 & 6718 & $1,446,304$ & 36,742 & 28,008 & 1648 & $1,582,225$ \\
\hline $\begin{array}{l}2019 \text { (first } \\
\text { half) }\end{array}$ & 32,237 & 4915 & 764,759 & 20,426 & 22,295 & 1297 & 845,929 \\
\hline
\end{tabular}

Source: Ministry of Family, Labour and Social Policy, Poland (Employment of foreigners in Poland/Zatrudnianie cudzoziemców w Polsce. https://psz.praca.gov.pl/rynek-pracy/statystyki-ianalizy/zatrudnianie-cudzoziemcow-w-polsce Accessed 13 December 2019)

\footnotetext{
${ }^{53}$ For more details see Górny et al. (2018), pp. 26-27.

${ }^{54}$ See ibid. See also Pawlak and Lashchuk (forthcoming).

${ }^{55}$ Ibid.
} 


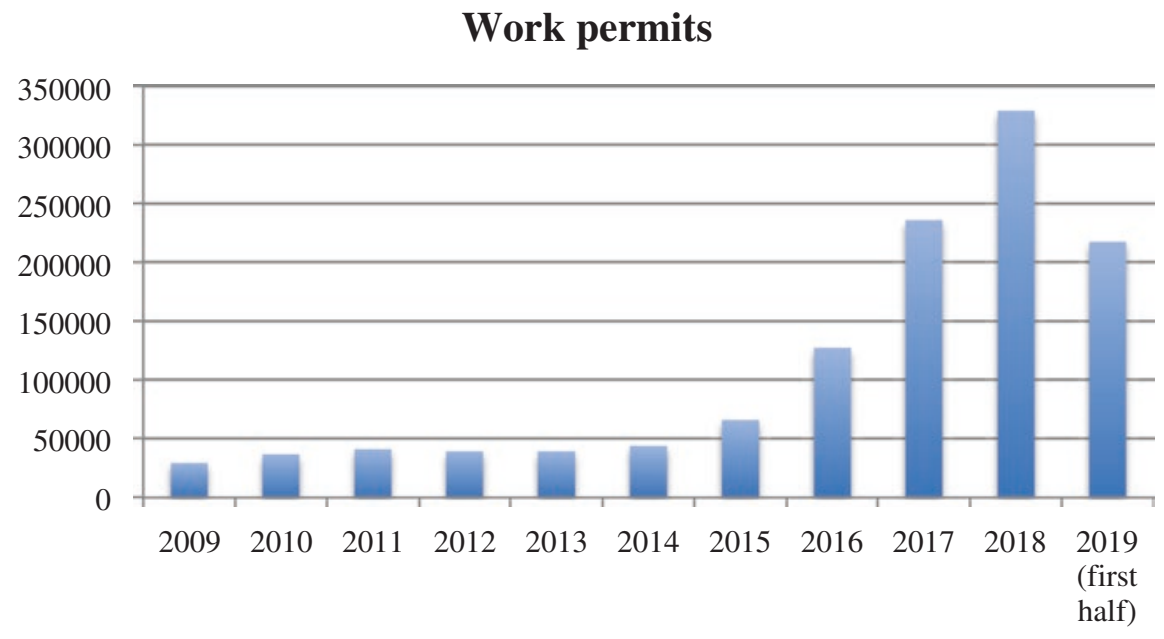

Fig. 6.1 Work permits in Poland in the period 2009 - first half of 2019. Source: Author's own elaboration on the basis of data of the Ministry of Family, Labour and Social Policy, Poland (Work permits for foreigners/Zezwolenia na pracę cudzoziemców. https://psz.praca.gov.pl/web/urzadpracy/-/8180075-zezwolenia-na-prace-cudzoziemcow Accessed 13 December 2019)

more than ten times over the last decade to reach 328,768 in 2018 (see Fig. 6.1). Here again, it should be noted that the data cover both new and extended work permits with a validity of up to 3 years. Ukrainians are the group with the most work permits, reaching 238,334 in 2018. Another Eastern partnership country that stands out is Belarus; the number of work permits issued to citizens of this country increased in 2018 to reach 19,233.

The Ukrainian and Russian participants in the focus group conducted in late 2016 in Poland shared very diverse experiences with regards to circular migration, which in most of the cases presented a picture of circularity consisting of a chain of different trajectories supported by various instruments. Almost all of the Ukrainians and a few of the participants in the Russian focus group experienced, at some point in time, the Oświadczenie procedure, which they used both as an entry mechanism to Poland and as means of circulation. ${ }^{56}$ Several of them had experience of obtaining a 'fake" ${ }^{57}$ declaration that enabled them to enter Poland and look for a job, then afterwards obtain a new Oświadczenie (declaration) stating the real employment or use other ways to 'legalise their stay', e.g., by starting a course of study. The fake declarations were usually obtained through friends, acquaintances, or colleagues

\footnotetext{
${ }^{56}$ Focus groups with Russian and Ukrainian migrants, Poland, November 2016, Annex IV. Interview \#6 with lawyers, Poland, November 2016, Annex II.

${ }^{57}$ Meaning that the employer who issued the declaration had no intention of offering a job to the foreigner in question and its sole purpose was to enable the foreigner to obtain a visa and legally enter Poland to seek a job.
} 
who registered a declaration, stating that they needed the person in question. They could also be bought online through different social media channels for $100 \mathrm{USD}^{58}$ or through intermediaries in Ukraine for 200-250 USD ${ }^{59}$ in cases when the migrants did not know anyone in Poland who could register a declaration on their behalf. ${ }^{60}$

The analysis of the data gathered through the focus groups and interviews shows that the migrants using the Oświadczenie procedure for the purposes of circular migration did not face any problems with regards to entry and re-entry conditions when the registered declaration was filled in properly. ${ }^{61}$ One of the participants in the Ukrainian focus group remarked that he was deported due to a discrepancy between the information about his work place submitted in the declaration by the employer and the actual work place ${ }^{62}$; he appealed this decision successfully, stating that this was a mistake by the employer, and was eventually allowed to return to Poland.

The participants using the Oświadczenie procedure as an entry mechanism shared that the majority of them had trouble finding a job in Poland that would have allowed them to come on a work visa. ${ }^{63}$ Using the declaration system gave them time to come to Poland, look for a job, and convince an employer to hire them so that they could begin the procedure for obtaining the single permit. ${ }^{64}$ In the case of the recently arrived Ukrainians, this was the fastest way of leaving Ukraine on account of the political situation (instead of applying for asylum) or actually entering Poland as soon as possible before 'some new regulations were introduced in January 2017' (the then-pending changes due to the transposition of the Seasonal Workers' Directive). ${ }^{65}$

The interviews conducted with representatives of the administration brought another perspective to the use of this procedure. According to the officials who were interviewed in late 2016, due to its liberal character, the procedure was often abused by both migrant workers and employers. ${ }^{66}$ One of the most frequent problems was caused by employers who issued more declarations than the actual number of

\footnotetext{
${ }^{58}$ Focus group with Russian migrants, Poland, November 2016, Annex IV.

${ }^{59}$ Interview \#1 with officials, Poland, November 2016, Annex II. Interview \#6 with lawyers, Poland, November 2016, Annex II. Interview \#5 with civil society representative, Poland, November 2016, Annex II. Interview \#10 with staff member of a private recruitment agency, Poland, October 2016, Annex II.

${ }^{60}$ Focus group with Ukrainian migrants, Poland, November 2016, Annex IV.

${ }^{61}$ Focus groups with Russian and Ukrainian migrants, Poland, November 2016, Annex IV. Interview \#9 with employer, Poland, December 2016, Annex II.

${ }^{62}$ Focus group with Ukrainian migrants, Poland, November 2016, Annex IV.

${ }^{63}$ Focus groups with Russian and Ukrainian migrants, Poland, November 2016, Annex IV.

${ }^{64}$ Focus groups with Russian and Ukrainian migrants, Poland, November 2016, Annex IV. Interview \#6 with lawyers, Poland, November 2016, Annex II.

${ }^{65}$ Focus group with Ukrainian migrants, Poland, November 2016, Annex IV. Interview \#7 with official, Poland, November 2016, Annex II. Interview \#6 with lawyers, Poland, November 2016, Annex II. Amendments were introduced as of January 2018.

${ }^{66}$ Interview \#1 with officials, Poland, November 2016, Annex II. See also Górny et al. (2018).
} 
seasonal workers required as a way of ensuring that some migrant workers would eventually come and work for them. Another issue stemmed from migrants who used the Oświadczenie procedure to access the Schengen zone and did not begin working for the employer who registered the declaration. The officials shared that they received information from their colleagues in other Member States that there were irregularly-working migrants who entered on a visa issued on the basis of the Oświadczenie procedure. ${ }^{67}$ Very often migrant workers would use this procedure when they wished their relatives to visit them because it was cheaper and faster than applying for a tourist visa. ${ }^{68}$ These problems contributed to the overburdening of Ukrainian consulates, which had to handle the increased volume of visa applications. The large queues for submitting visa applications caused delays and was conducive to corruption that was facilitated by intermediaries, who were in fact 'selling' places in the queues. ${ }^{69}$

Another instrument related to the circular migration experience of the focus group participants was the Karta Polaka. ${ }^{70}$ The scarce public information available on the number of cards issued demonstrates that mostly Belarusians $(111,932)$ and Ukrainians $(101,934)$ have benefited from this instrument in the period 2008-2017. ${ }^{71}$ In the same period, 5586 Russians, 1629 Moldovans, 156 Georgians, 125 Azerbaijanis, and 89 Armenians also obtained such cards.

Both Russians from Kaliningrad and Ukrainians used this instrument and found it very useful in aiding their circularity between Poland and their countries of origin. Furthermore, they shared that it saved them from having to go through many bureaucratic hurdles ('Queues, losses of documents, prolonging issue time, and all those horrible things ${ }^{72}$ ) that most of their friends faced when applying for residence permits. ${ }^{73}$ One of the participants shared:

'I obtained Karta Polaka and since then I had no problems with visas, because the consulate has a very good attitude to Polish people. You come with Karta Polaka and all will be done fast and without any problems. There are some special regulations, which simplified the procedure and allowed to obtain visa in easier way. So it is not because they like us but there is a legislation which allows them to do it in this way. ${ }^{74}$

\footnotetext{
${ }^{67}$ Interview \#1 with officials, Poland, November 2016, Annex II.

${ }^{68}$ Also in Interview \#3 with civil society actor, Poland, November 2016, Annex II and Interview \#2 with academic, Poland, November 2016, Annex II.

${ }^{69}$ Interview \#1 with officials, Poland, November 2016, Annex II; also in interview \#3 with civil society actor, Poland, November 2016, Annex II and Interview \#2 with academic, Poland, November 2016, Annex II.

${ }^{70}$ See Chap. 5, Sect. 5.2.1.2 for background information.

${ }^{71}$ Statistics Poland (2018), p. 454.

${ }^{72}$ Focus group with Russian migrants, Poland, November 2016, Annex IV.

${ }^{73}$ Focus group with Russian migrants, Poland, November 2016, Annex IV.

${ }^{74}$ Focus group with Russian migrants, Poland, November 2016, Annex IV. The latest amendments to the preamble of the Act on the Pole's Card in 2019, however, clearly show that the Polish government perceives these cardholders as Poles and therefore they are treated differently than regular visa applicants. See the Act of 16 May 2019 amending the Act on the Pole's Card/Ustawa z dnia
} 
Another entry mechanism used by some of the focus group participants was an education visa, which led to a circular migration trajectory at a certain point in time. Some of them studied in Poland or obtained educational grants from Polish institutions; they returned to their countries of origin several times and then migrated back to Poland for employment purposes, where they eventually changed their status by applying for the EU long-term residence in one of the cases or for the Karta Polaka. ${ }^{75}$

Unlike Poland, Bulgaria does not regularly publish public data on the employment of foreigners. The available data are scarce and dispersed among ad hoc reports and other governmental documents, which all have the Bulgarian Employment Agency as a source. The only way to obtain data for a particular period is through official requests for access to public information. Yet, when the Employment Agency's data obtained in different years are compared, one can see discrepancies in the number of permits reported in a given year. Furthermore, according to the different publicly available reports, the number of foreigners who gained access to the Bulgarian labour market varies in that same year despite all quoting the Employment Agency data as the original source. ${ }^{76}$ Finally, there are discrepancies between the same type of data provided by different institutions, such as the Ministry of Interior and the Employment Agency. These discrepancies could be attributed to different definitions used by institutional actors as well as data corrections that are not being communicated publicly. Keeping in mind the above caveats, the data obtained through official requests for information are presented in this section in order to provide a comparison with the Polish case and an indication of labour migration trends in Bulgaria.

According to the Employment Agency's data, close to 10,000 work permits both new and extended - have been issued to foreigners in the period between 2009 and the first half of $2019 .{ }^{77}$ This number indicates all foreigners who have obtained authorisation for access to the Bulgarian labour market, such as single permit holders, Blue Card holders, ICTs, seasonal workers residing up to 9 months on the basis of a work permit, and posted workers from third countries. It excludes, however, seasonal workers residing in Bulgaria for a period of up to 90 days. The data show that after stabilising at around an average 600 work permits annually for a period of 7 years after the economic crisis, there was a gradual increase in the number of work

16 maja 2019 r. o zmianie ustawy o Karcie Polaka (Dziennik Ustaw z 2019 r., poz. 1095). The author wishes to thank prof. Witold Klaus for this comment.

${ }^{75}$ Focus groups with Russian and Ukrainian migrants, Poland, November 2016, Annex IV.

${ }^{76}$ For instance, according to different sources, which all refer to the Employment Agency's data, the number of work authorisations issued to foreigners in 2018 ranges from 1904 to 7056 . The first figure is published in the report of the National Council on Migration and Integration (2019); the second is from the report on Bulgaria of the European Migration Network (2018) (again produced by the administration). The data obtained through an official request for information indicate that 1642 work authorisations were issued in 2018.

${ }^{77}$ Information obtained via an official request for information under Decision N. РД-08-2156 from 12.08.2019 of the general secretary of the Employment Agency. 


\section{Work permits}

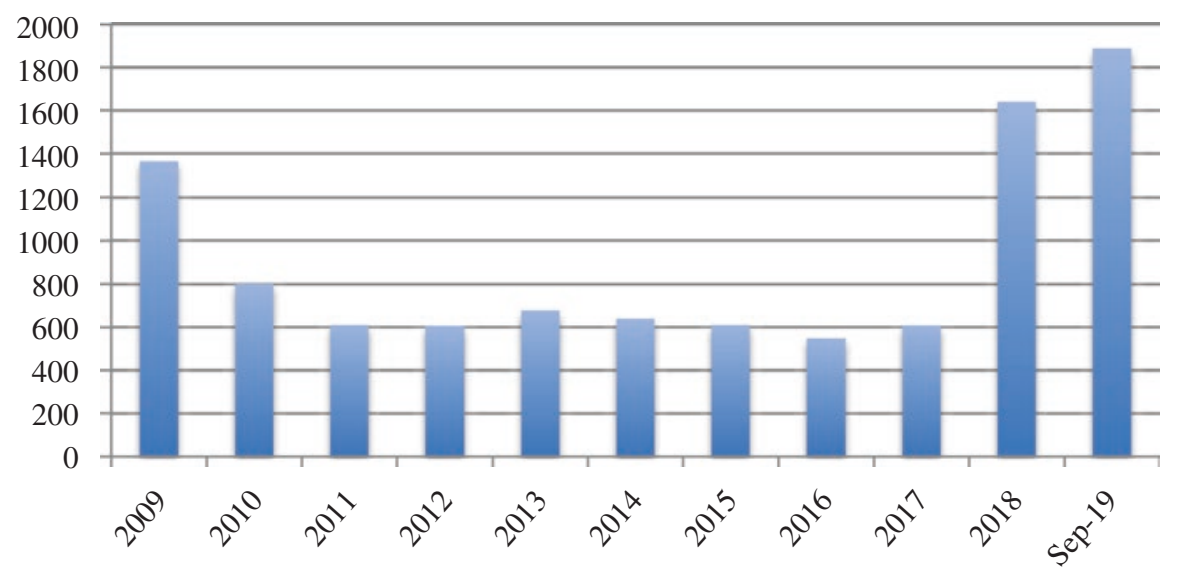

Fig. 6.2 New and extended work permits in Bulgaria in the period 2009 - first half of 2019 . Source: Author's own elaboration on the basis of data of the Employment Agency, Bulgaria (Information obtained via an official request for information under decision No. РД-08-2156 from 12.08.2019 of the general secretary of the Employment Agency)

permits issued in the last 2 years (see Fig. 6.2) ${ }^{78}$ Most of the work permits in 2018 were granted to Turkish workers (640), followed by Ukrainians (294) and Serbians (118). In the first half of 2019, the number of work permits issued to Ukrainians (404) surpassed the number of permits granted to Turkish workers, and there was an increase in the number of work permits issued to Moldovans (95) and Kyrgyzstanis (247). ${ }^{79}$

In addition, the number of seasonal workers residing in Bulgaria for a period of up to 90 days has increased exponentially (see section 6.3.3.4 for more details). ${ }^{80}$ This increase in labour migration can be attributed to the country's economic growth and rising demand for foreign labour, as well as the procedures established for the recruitment of third-country nationals as seasonal workers as a result of the implementation of the Seasonal Workers Directive and the liberalised access to the Bulgarian market for certain categories of workers.

During the recruitment process for the focus groups in Bulgaria, it was a challenge to find migrant workers employed on labour contracts. This was due to the restrictive entry conditions that were dependent on the performance of a labour market test as a requirement for obtaining a work permit. These impediments forced

\footnotetext{
${ }^{78}$ Ibid.

${ }^{79}$ Ibid.

${ }^{80}$ Ibid.
} 
most of the foreigners to resort to different channels to circumvent the entry procedure. ${ }^{81}$

According to one of the lawyers interviewed, the labour market test led to migrants being dependent on the employer and thus created a breeding ground for corruption. Furthermore, it was remarked that:

'[t]hey need to find someone to do this test for them. This test is a formality, does not prove anything and it leaves discretion in the hands of the administration that can refuse to issue a permit. Who is going to fight for you? You need to be exceptional for the employer to be willing to go through all this. ${ }^{82}$

One of the employers interviewed mentioned that he wished to employ Russianspeaking foreigners, however, she stressed that this was very difficult and that there were many hurdles impeding migrants' ability to obtain the necessary visa type D. ${ }^{83}$ The interviewee explained that she would like to hire a cook but that it would be very difficult to obtain a visa for such person just because it is 'an ordinary job'. One of the lawyers interviewed also commented on this procedure, saying that it was very hard to prove that a migrant was 'unique', e.g., the cook needed to be hired to work in an 'exotic' restaurant in order to be able to pass the labour market test. ${ }^{84}$ Therefore, the employer interviewed preferred to hire migrants who were already in the country: 'I cannot imagine how much money, time and nerves I would need to waste in order to obtain a visa D for a foreigner I want to hire!' ${ }^{85}$

The state officials interviewed, on the other hand, claimed that the test was a requirement that aimed to protect the labour market and 'keep Bulgarians with high qualifications here' ${ }^{86}$ In line with this policy, the fee that the employer was required to pay for a work permit was deliberately high compared to the fees of other administrative documents for Bulgarians until 2017 when it was reduced to 100 BGN (50 EUR) as part of the amendment to the ALMLM ${ }^{87}$ Foreigners were supposed to come on a temporary basis in order to train Bulgarian workers, and the aim of the 3-year period of validity of the work permit was to allow Bulgarians to qualify for the position in question. ${ }^{88}$

According to the migrants interviewed, restrictive access to the Bulgarian labour market and the labour market test requirement meant that many foreigners entered Bulgaria via registration of a trade representation and sought

\footnotetext{
${ }^{81}$ Interviews \#8 and \#9 with lawyers, Bulgaria, July 2016, Annex III; focus groups with Russian and Ukrainian migrants, Bulgaria, September 2016, Annex IV.

${ }^{82}$ Interview \# 9 with lawyer, Bulgaria, July 2016, Annex III; also in focus group with Russian migrants, Bulgaria, September 2016, Annex IV.

${ }^{83}$ Interview \#19 with foreign employer, Bulgaria, September 2016, Annex III.

${ }^{84}$ Interview \#8 with lawyer, Bulgaria, July 2016, Annex III.

${ }^{85}$ Interview \#19 with foreign employer, Bulgaria, September 2016, Annex III.

${ }^{86}$ Interview \#10 with officials, Bulgaria, July 2016, Annex III.

${ }^{87}$ See SG No. 97/ 5 December 2017.

${ }^{88}$ Interview \#10 with officials, Bulgaria, July 2016, Annex III.
} 
employment later (Article 24 (1) 6 of the AFRB). ${ }^{89}$ The trade representation was used only as grounds for entry, on the basis of which a residence permit was issued but it did not give the individual the right to work (Article 8 (1) 2 of the ALMLM). After entering the country, many of the migrants registered a Bulgarian company so that they could exercise economic activity (as managers). However, this did not give them access to the labour market as employees. The alternative grounds for entry contained in the Act on Foreigners required the foreigner to register a firm as well as provide ten job positions for Bulgarians an impossible condition for a small, fledgling business to meet, according to the migrants interviewed and other respondents..$^{90}$

An alternative option for migrant workers was to use a multiple-entry visa type $\mathrm{C}$ to undertake short periods of work in Bulgaria and subsequently receive their remuneration in their country of origin. However, the Ukrainian participants in the focus group shared that this was neither good for their family nor for their business. Well-off Russians often used the grounds contained in Article 25 of the AFRB and invested in Bulgarian property of a value of 500,000 EUR, which gave them the opportunity to directly obtain permanent residence and secure housing. The permit also allowed them access to the labour market. Even Russian pensioners who had bought a flat whose price was not high enough to be considered an investment still needed to obtain a visa. In order to circumvent the law and obtain a residence permit, they thus registered a trade representation so that they could circulate freely and with minimal expense. ${ }^{91}$ One of the participants in the focus groups added: 'Another entry option is to get married'.

The migrants interviewed in the focus groups described the reality in Bulgaria as 'forced circularity'. For most, being granted an EU long-term residence status was the desired option, rather than engaging in circular migration. Bulgarian migration law is based on the premise that in order to change one's status (including from visa type $\mathrm{C}$ to $\mathrm{D}$ ) or renew one's permit after reaching the maximum period allowed, in most of the cases a person needs to leave Bulgaria and re-apply from another country. ${ }^{92}$ According to one of the lawyers interviewed, this was a result of the logic of the law that ' $[\mathrm{t}]$ he foreigner must suffer' ${ }^{93}$ The Russian participants in one of the focus groups shared that 'when you need to go out to change your visa from C to D and pay so much, you do not want to circulate'.

According to ALMLM's provisions, migrant workers can stay in Bulgaria for a maximum period of 3 years before they need to leave and re-apply from abroad which means that a labour market test will have to be performed again. An interviewee commented on this provision as follows:

\footnotetext{
${ }^{89}$ Focus groups with Russian and Ukrainian migrants, Bulgaria, September 2016, Annex IV.

${ }^{90}$ Interview \#18 with representatives of an IT company, Bulgaria, September 2016, Annex III.

${ }^{91}$ Focus groups with Russian and Ukrainian migrants, Bulgaria, September 2016, Annex IV.

${ }^{92}$ See also European Migration Network (2015).

${ }^{93}$ Interview \#8 with lawyer, Bulgaria, July 2016, Annex III.
} 
'If sent back home after 3 years, the migrant is discouraged to return! Everyone looses. Re-entry is not guaranteed. You can be refused visa D, which means a waste of time, money and opportunities. Who would risk coming back if he/she can go somewhere else?'94

The Russians who were trying to reach the 5-year threshold in order to obtain an EU long-term residence shared that they paid 350 EUR per year per person in order to renew their residence permit and their ID card, ${ }^{95}$ and that voluntary "circular migration would be a big risk' ${ }^{96}$

Along with the restrictive entry conditions, foreigners who decide to apply for a work permit face additional hurdles as part of a cumbersome single application procedure.$^{97}$ As the European Commission stresses in its Implementation Report on the Single Permit Directive, in Bulgaria this procedure does not entail a single administrative act but duplication of submission of documents and therefore is prone to cause long delays.

\subsection{Entry and Re-entry Conditions as Provided by EU Legal and Policy Instruments Implemented at the National Level}

\subsubsection{EU Visa \& GAMM Instruments Facilitating Circular Migration}

As discussed in Chap. 4, when analysing the implementation of EU's approach to circular migration, it is also important to take into consideration the instruments and initiatives developed as part of the EU Visa policy and the GAMM framework. In line with its bilateral relations in the context of the Eastern Partnership, Poland actively supports the efforts directed at visa facilitation at the EU level. ${ }^{98}$ Both Bulgaria and Poland benefit from the already-concluded visa facilitation agreements with the Eastern Partnership countries and participate in activities under the auspices of GAMM. Both are parties to the Mobility Partnerships with Moldova (2008), Georgia (2009), Armenia (2011), Azerbaijan (2013), and Belarus (2016) respectively.

In addition, after the Local Border Traffic Regulation 1931/2006 ${ }^{99}$ was adopted at the EU level, Poland signed an agreement with Ukraine, which entered into force

\footnotetext{
${ }^{94}$ Interview \#9 with lawyer, Bulgaria, July 2016, Annex III.

${ }^{95}$ This has been reduced as a result of the amendments to Article 10 of Tariff No. 4.

${ }^{96}$ Focus groups with Russian migrants, Bulgaria, September 2016, Annex IV.

${ }^{97}$ European Commission (2019a), pp. 4-5.

${ }^{98}$ European Migration Network (2012), p. 32.

${ }^{99}$ Regulation No. 1931/2006 of the European Parliament and of the Council of 20 December 2006 laying down rules on local border traffic at the external land borders of the Member States and amending the provisions of the Schengen Convention [2006] OJ L 405.
} 
in July 2009, ${ }^{100}$ and concluded another agreement with Belarus in February 2010. Both parties have ratified the latter agreement but the formal finalisation of the procedure by the Belarusian government is still pending. ${ }^{101}$ During the Polish presidency of the Council, a local border traffic agreement for the Kaliningrad region was signed after 2 years of negotiations. ${ }^{102}$ Such an agreement required an exception to Article 3 (2) of the Local Border Traffic Regulation 1931/2006 that would allow the entire Kaliningrad region to be considered as a border area. ${ }^{103}$ The bilateral agreement between Poland and the Russian Federation entered into force on 27 July 2012, allowing for reciprocal visa-free entry for up to 30 days. ${ }^{104}$ However, because of tense relations between the two countries, it was suspended in 2016 due to a NATO summit; the suspension was initially for 1 month but the agreement has not been reintroduced since..$^{105}$

Currently the only bilateral local border traffic agreement in force between Poland and its eastern neighbours is the 2009 agreement with Ukraine. The Polish Act on Foreigners stipulates the general provisions on the crossing of the border under the local border traffic regime. ${ }^{106}$ Since the text of the agreements that Poland concluded is analogous, ${ }^{107}$ the information presented below also covers the agreement with the Kaliningrad region and provides some insights into the pending agreement with Belarus. According to the agreements, border area residents

\footnotetext{
${ }^{100}$ See Agreement between the Government of the Republic of Poland and the Cabinet of Ministers of Ukraine on local border traffic rules signed in Kiev on 28 March 2008, and Protocol signed in Warsaw on 22 December 2008 between the Government of the Republic of Poland and the Cabinet of Ministers of Ukraine on amending the Agreement between the Government of the Republic of Poland and the Cabinet of Ministers of Ukraine on local border traffic rules signed in Kiev on 28 March 2008/Umowa między Rządem Rzeczypospolitej Polskiej a Gabinetem Ministrów Ukrainy o zasadach małego ruchu granicznego, podpisana w Kijowie dnia 28 marca 2008 r., oraz Protokół, podpisany w Warszawie dnia 22 grudnia 2008 roku, między Rządem Rzeczypospolitej Polskiej a Gabinetem Ministrów Ukrainy o zmianie Umowy między Rządem Rzeczypospolitej Polskiej a Gabinetem Ministrów Ukrainy o zasadach małego ruchu granicznego, podpisanej w Kijowie dnia 28 marca 2008 r. (Dziennik Ustaw z 2009 r., poz. 858).

${ }^{101}$ For more information, see Znadniemna (2018).

${ }^{102}$ For more details, see Fomina (2011).

${ }^{103}$ Regulation No. 1342/2011 of the European Parliament and of the Council of 13 December 2011 amending Regulation No. 1931/2006 as regards the inclusion of the Kaliningrad oblast and certain Polish administrative districts in the eligible border area [2011] OJ L 347.

${ }^{104}$ OECD (2013), p. 284. Agreement between the Government of the Republic of Poland and the Government of the Russian Federation on local border traffic rules signed in Moscow on 14 December 2011/Umowa między Rządem Rzeczypospolitej Polskiej a Rządem Federacji Rosyjskiej o zasadach małego ruchu granicznego, podpisana w Moskwie dnia 14 grudnia 2011 r. (Dziennik Ustaw z 2012 r., poz. 814).

${ }^{105}$ Radio Poland (2016).

${ }^{106}$ Articles 37-48 AF.

${ }^{107}$ Wasilewska (2008), p. 10.
} 
are persons with documented permanent residence in the border area ${ }^{108}$ for a period of at least 3 years; the status includes spouses and dependent children. ${ }^{109}$

A permit can be issued to a border resident who holds a valid travel document, presents proof of permanent residence in the border area for at least 3 years, and has a legitimate reason for frequently crossing the respective border which, according to the legislation of the contracting parties, does not constitute gainful activity or gainful employment. ${ }^{110}$ A local border permit holder can cross the border an unlimited number of times but can only stay in the designated border areas for a period of up to 60 days from the date of entry in the case of Ukrainian citizens and 30 days in the case of Russian citizens; in both cases, however, the total period of stay cannot exceed 90 days during any given 6 months from the date of first entry. ${ }^{11}$

\subsubsection{EU Visa \& GAMM Instruments Facilitating Circular Migration - Implementation Dynamics}

In response to the Communication of the Commission on Mobility Partnerships and Circular Migration in 2007, the Polish government decided to expand the Oświadczenie procedure as part of the GAMM. ${ }^{112}$ Therefore, this instrument possesses a dual role - a national instrument facilitating circular migration, and an initiative introduced as part of the GAMM. One interviewee claimed that the Polish representatives involved in the management of the Mobility Partnerships were asked by the European Commission to promote the Oświadczenie procedure as a circular migration scheme: 'they take anything that looks like it and put the label'. ${ }^{113}$

Initially only open to Ukraine, Belarus, and Russia, the Oświadczenie procedure was gradually included in the scoreboards of the countries of the Eastern Partnership that concluded Mobility Partnerships with some of the EU Member States. In practice, however, this procedure is used for circulation purposes mainly by citizens of the neighbouring areas - mostly from Ukraine, Kaliningrad, and Belarus. There are several reasons for this. First, according to the experts interviewed, the act of extending the Oświadczenie procedure to the Eastern Partnership countries was a matter of

\footnotetext{
${ }^{108}$ The Agreement with Ukraine covers the border area zone up to $30 \mathrm{~km}$ from the shared border. The suspended agreement with the Russian Federation provided that the local border traffic regime applies to all inhabitants on the Russian side of the Kaliningrad region and on the Polish side includes the residents of large parts of the Pomerania and Warmia-Mazury provinces respectively.

${ }^{109}$ See for example Article 2 (1) e and (2) of the Agreement between the Government of the Republic of Poland and the Government of the Russian federation on the Rules of Local Border Traffic.

${ }^{110}$ Article 3 (1) of the Agreement between the Government of the Republic of Poland and the Government of the Russian federation on the Rules of Local Border Traffic.

${ }^{111}$ Migrantinfo.pl (2018).

${ }^{112}$ Interview \#18 with official, Poland, November 2016, Annex II.

${ }^{113}$ Interview \#12 with academic, Italy, May 2013, Annex II.
} 
foreign policy rather than a development driven by Poland's migration policy. ${ }^{114}$ Therefore, this instrument was not advertised among the local population after the conclusion of the Mobility Partnerships with Armenia and Georgia.

Second, in practice it is mainly the nationals of the neighbouring countries who were interested in this type of migration because of the costs related to migration. Even though Ukraine is the only Eastern Partnership country that has not signed a Mobility Partnership, according to the official statistical data (see Table 6.1), Ukrainians were the main beneficiaries of the Oświadczenie procedure. Some of the interviewed experts claimed that it was purposefully designed as a tool to primarily attract Ukrainians. ${ }^{115}$ An official stressed that Ukrainians started to circulate between Poland and Ukraine as early as the 1990s: 'it is not like we invented the system and they started to circulate'. ${ }^{116}$ This circulation in the border region between Poland and Ukraine is supported by well-established informal channels for recruitment of agricultural workers through a network of bus drivers. ${ }^{117}$ Along with its geographical proximity, Poland also attracts Ukrainians because of the historical, cultural, and linguistic proximity between the two countries. ${ }^{118}$

Finally, another pull factor was the higher earnings for Ukrainians from a couple of months of work in Poland that, in turn, enabled them to support their families when they returned home. As one of the interviewed employers stated, 'the ones who need some additional money would come for 1 or 1.5 months to pick apples or strawberries. A pensioner would get around 300 zloty (70 EUR) as a pension and would earn about 80-100 zloty (19-24 EUR) per day in Poland'. ${ }^{119}$

By way of comparison, Bulgaria has praised the GAMM, ${ }^{120}$ supported the Eastern Partnership, and joined the Mobility Partnerships signed with five of the Eastern Partnership countries. According to the latest National Migration Strategy, this stems from the fact that Bulgaria identified the Eastern Partnership countries as its main partners within the context of the GAMM. ${ }^{121}$ Along with the bilateral agreements with the Eastern Partnership countries concluded as part of the Mobility

\footnotetext{
${ }^{114}$ Interview \#1 with officials, Poland, November 2016, Annex II; Interview \#4 with expert, Poland, December 2016, Annex II; Interview \# 18 with official, Poland, November 2016, Annex II.

${ }^{115}$ Interview \#1 with officials, Poland, November 2016, Annex II; Interview \#15 with academic, Poland, November 2016, Annex II; Interview \#4 with expert, Poland, December 2016, Annex II.

${ }^{116}$ Interview \#1 with officials, Poland, November 2016, Annex II.

${ }^{117}$ Interview \#9 with official, Poland, November 2016, Annex II. See also Bieniecki and Pawlak (2009).

${ }^{118}$ Interview \#10 with staff member of a private recruitment agency, Poland, October 2016, Annex II. See also Kindler et al. (2016).

${ }^{119}$ Interview \#9 with official, Poland, November 2016, Annex II.

${ }^{120}$ Lessenski (2009), p. 46.

${ }^{121}$ National Strategy in the field of Migration, Asylum and Integration (2015-2020), p. 27; also in Interview \#1 with official, Bulgaria, July 2016, Annex III.
} 
Partnerships, ${ }^{122}$ Bulgaria has also been interested in participating in the range of the GAMM initiatives with other migrant-sending countries to the EU. ${ }^{123}$

Both countries participate in the projects being implemented by the International Organization for Migration (IOM) and the International Centre for Migration Policy Development (ICMPD) in the Eastern Partnership countries, such as those carried out under the auspices of the Prague Process. In addition, as noted in Chap. 4, IOM Georgia implemented the 'Temporary Labour Migration of Georgian Workers to Poland and Estonia' project with the aim of developing operational frameworks to facilitate worker mobility from Georgia to Poland and Estonia that would, in turn, promote effective job-matching, migrant skill development, and protection of their labour and human rights. ${ }^{124}$ According to the IOM office in Georgia, the spontaneous character of Georgians' labour migration using the Oświadczenie procedure did not allow the Georgian government to adequately respond to national workforce development needs and ensure better skills match to the Polish labour market's demands in the long-term. ${ }^{125}$

Poland also participated in another initiative aimed at facilitating labour mobility as part of the 'Ulysses' project implemented by Armenia's International Centre for Human Development (ICHD) and focused on matching European employers with Armenian job seekers. Even though the system established as a result of the project was 'very informative', it did not lead to a significant increase in the number of Armenians willing to work in Poland (see Table 6.1 and Fig. 6.1). ${ }^{126}$ An interviewee claimed that distance was one of the main obstacles because travelling from Armenia to Poland was expensive.

One of the participants in the Russian focus group in Poland shared her experience with multiple-entry visas under the visa facilitation agreement with the Russia. ${ }^{127}$ The participant, who was from Kaliningrad, shared that these types of agreements simplified the entry procedure and 'really facilitate it for people from Russia and Ukraine, as it is easier for them to get visa and they can avoid issuing residency card'. ${ }^{128}$ She was eligible for a multiple-entry visa for a period of several years. After a change of the local consul, who started to demand more additional documents, and due to the changed nature of her work in Poland, which required longer periods of stay there, she decided to apply for a Pole's Card in order to be able to circulate between the two countries without encountering problems. ${ }^{129}$

\footnotetext{
${ }^{122}$ For more details, see Chap. 4, Sect. 4.2.3.

${ }^{123}$ Council of Ministers (2015), p. 27.

${ }^{124}$ International Organization for Migration Mission to Georgia (2017).

${ }^{125}$ Ibid.

${ }^{126}$ Interview \#10 with staff member of a private recruitment agency, Poland, October 2016, Annex II.

${ }^{127}$ See Agreement between the European Community and the Russian Federation on the facilitation of the issuance of visas to the citizens of the European Union and the Russian Federation [2007] OJ L129.

${ }^{128}$ Focus group with Russian migrants, Poland, November 2016, Annex IV.

${ }^{129}$ Focus group with Russian migrants, Poland, November 2016, Annex IV.
} 


\subsubsection{Legal Migration Directives Aiming to Facilitate Circular Migration and Their Implementation Dynamics}

\subsubsection{Blue Card Directive}

The Blue Card Directive ${ }^{130}$ was transposed into the Polish Act on Foreigners through the introduction of a special temporary residence permit for the purposes of highlyqualified employment, referred to as the 'EU Blue Card permit', which is issued through a single administrative procedure. ${ }^{131}$ Article 127 thereof lists the conditions that must be fulfilled in order for the permit to be granted. The foreigner needs to have concluded an employment, tolling, or civil law agreement of a minimum of 1 year that provides for an annual gross remuneration no less than the equivalent of $150 \%$ of the average monthly salary in the national economy during the preceding calendar year. ${ }^{132}$ The applicants must fulfil the qualification requirements and other conditions in cases where they are to perform work in a regulated profession, as defined by Article 5 (4) of the Act of 22 December 2015 on the rules governing recognition of professional qualifications acquired in EU Member States. ${ }^{133}$ Furthermore, applicants must possess the authorisation of a competent authority to hold a given position or pursue a given profession or activity, where the obligation to obtain it before entering into the agreement stems from separate regulations. ${ }^{134}$ Additionally, foreigners must have a higher professional qualification, meaning that they have completed at least a 3-year course of study at a higher education institution or have 5 years of professional experience in a field that is compatible with the profession. ${ }^{135}$ Finally, applicants must have health insurance or a confirmation of insurance coverage for any treatment that may be required on Polish territory.

In Bulgaria, residence and work permits of the 'EU Blue Card type' can be granted to foreigners holding a visa under Article 15 (1) or a continuous residence permit on other grounds and who are identified as highly-qualified workers pursuant to the provisions of the ALMLM (Article 33к (1) of the AFRB). It needs to be

\footnotetext{
${ }^{130}$ Council Directive 2009/50/EC of 25 May 2009 on the conditions of entry and residence of thirdcountry nationals for the purposes of highly qualified employment [2009] OJ L 155/17.

${ }^{131}$ Unterschütz (2016), p. 184.

${ }^{132}$ Announced by the President of the Central Statistical Office in accordance with Article 20 (1) (a) of the Act of 17 December 1998 on Old-Age and Disability Pensions from the Social Insurance Fund/ Ustawa z dnia 17 grudnia 1998 r. o emeryturach i rentach z Funduszu Ubezpieczeń Społecznych (Dziennik Ustaw z 2018 r. poz. 1270, consolidated text).

${ }^{133}$ Ustawa z dnia 22 grudnia 2015 r. o zasadach uznawania kwalifikacji zawodowych nabytych w państwach członkowskich Unii Europejskiej (Dziennik Ustaw z 2018 r. poz. 2272, consolidated text).

${ }^{134}$ Article 127 (1) (e) AF.

${ }^{135}$ Article 127 (1) (c) AF.
} 
stressed that before the amendment of the Act on Foreigners in December 2017, only foreigners residing in a third country could apply for this permit. ${ }^{136}$

The Employment Agency issues the work authorisation, which is part of the Blue Card permit, in line with the general application procedure contained in Article 7 (1) 3 and 4 of the ALMLM. Foreigners must fulfil the required professional qualification and the gross salary referred to in their labour contract should be at least 1.5 times higher than the average salary in Bulgaria, according to the data available for the last 12 months, before the conclusion of the employment contract (Article 17 (2) of the ALMLM). Even though this provision only stipulates a requirement for a higher education qualification, Article 15 (2) in conjunction with Article 2 (1) 4 of the Implementing Regulation of ALMLM, requires both higher education qualification and professional experience - which is contrary to what is stipulated in Article 2 (g) of the Blue Card Directive. ${ }^{137}$ Furthermore, as part of the application process, the employer also needs to submit to the Employment Agency a copy of the concluded fixed labour contract with the employee that provides for the obligations of the parties concerning sickness insurance (Article 2 (1) 9 in conjunction with Article 2 (4) of the Implementing Regulation of ALMLM).

In line with Article 6 of the Directive, Poland requires the execution of a labour market test as part of the Blue Card application procedure, showing that the employer cannot 'satisfy its staffing needs with the local labour market'. ${ }^{138}$ The procedure for conducting a labour market test follows the one described earlier and is commensurate with Article 88c of the Act of 20 April 2004 on Employment Promotion and Labour Market Institutions. ${ }^{139}$ The labour market test is required only during the first 2 years of a foreigner's stay as a Blue Card holder in Poland. ${ }^{140}$ In addition, Article 129 provides for several exemptions from the test, for instance, when the profession that the foreigner will perform in Poland is part of the list of professions and types of work in short supply in the local labour market, as indicated by the governor. ${ }^{141}$ Exemptions from the labour market test are also possible if foreigners had a work permit or a residence and a work permit immediately before the filing of the application for the same employer, entrusting them to perform work in the same position or when they meet the conditions for exemption of a work permit regulated in the bylaws pursuant to Article 90 (5) of Act of 20 April 2004 on Employment Promotion and Labour Market Institutions.

In contrast, the labour market test and the $20 / 35 \%$ cap on the total number of third-country nationals who can be employed by a local employer as part of the general admission procedure in Bulgaria were waived for Blue Card applicants in

\footnotetext{
${ }^{136}$ Amendment to the AFRB from December 2017 (SG No. 97/ 5 December 2017).

${ }^{137}$ This also violates Article 15 of the Act on Normative Acts (SG No. 27/3 April 1973, last amendment SG No. 34/3 May 2016).

${ }^{138}$ Article 127 (2) AF.

${ }^{139}$ Article 136 AF.

${ }^{140}$ Article 129 (3) AF.

${ }^{141}$ Under Article 10 (4) 1 AEPLMI.
} 
May 2018. ${ }^{142}$ Before that, the labour market test was only waived if the profession was included on a List of Professions for which there was a shortage of highlyqualified specialists in line with the former Article 18 of the ALMLM. In 2016, after more than 2 years of lobbying by the IT sector in Bulgaria, the government exempted several IT positions from the labour market test in accordance with this article. $^{143}$

The Blue Card permit in Poland is granted for a period 3 months longer than the period during which work is to be performed, but for no longer than 3 years in total. ${ }^{144}$ This permit in Bulgaria is issued after a decision of the Employment Agency for a period of up to 4 years (Article 33k (2) of the AFRB). The possibility for extending the validity of the Blue Card permit for up to 4 years was provided through an amendment to the Act on Foreigners in late 2017. ${ }^{145}$ In cases where the term of the labour contract is shorter, the permit is issued for the period of duration of the contract, extended by 3 months (Article 33k (2) of the AFRB).

In 2016, the European Commission launched infringement proceedings against Bulgaria for the fees charged by the Ministry of Interior for issuing residence permits to foreigners. ${ }^{146}$ According to the Commission, the fees charged were not in compliance with the Blue Card Directive, the EU Long-term Residence Directive, the Family Reunification Directive, the Students' and Researchers' Directives, and the Single Permit Directive. The amended Tariff No. $4^{147}$ has led to a substantial decrease in the fees charged by the Ministry of Interior. Currently, Blue Card applicants are required to pay 110 BGN (56 EUR) for the residence right and 45 BGN (23 EUR) for the issue of an ID card (Articles 106 (6) and 46 (1) of Tariff No. 4). In comparison, Blue Card applicants in Poland pay 440 PLN (103 EUR) when they file the application and 50 PLN (11,75 EUR) for the residence card. ${ }^{148}$

According to Article 215 (1) 3 and 4 of the Polish Act on Foreigners, former Blue Card holders who obtain an EU long-term residence permit can have it revoked if they leave the territory of Poland for a period of more than 6 years or the territory of the EU for a period of 24 consecutive months. ${ }^{149}$ The same provision is contained in Article 40 (1) 11 of the Bulgarian Act on Foreigners.

\footnotetext{
${ }^{142}$ With amendment of the Act on Labour Migration and Labour Mobility of 16 March 2018 (SG No. 24/16 March 2018). The amended Article 17 (2) ALMLM now exempts Blue Card applications from the previously required labour market test.

${ }^{143}$ Interview \#18 with representatives of IT company, Bulgaria, September 2016, Annex III.

${ }^{144}$ Article 128 AFRB.

${ }^{145}$ Amendment to the AFRB from December 2017 (SG No. 97/ 5 December 2017).

${ }^{146}$ Infringement number 20164080, decision date 13 July 2017 concerning incorrect implementation (disproportionate charges) of Directive 2003/109/EC and other Directives by Bulgaria.

${ }^{147}$ Tariff No. 4 on the fees collected in the system of the Ministry of Interior under the State Fees Act (adopted with Council of Ministers Decree No. 53/1998, last amendment SG No. 75/ 11 September 2018).

${ }^{148}$ Mazowieckie For Foreigners (2019).

${ }^{149}$ For revocation grounds, see Article 133 in conjunction with Article $101 \mathrm{AF}$.
} 


\subsubsection{Blue Card Directive - Implementation Dynamics}

The Bulgarian administration issued 1221 Blue Card permits between January 2011 and mid-2019. ${ }^{150}$ Most of the Blue Card permits were granted to third-country nationals from Ukraine (344 permits) and Russia (296 permits), followed by China (84) and Turkey (76). ${ }^{151}$ Since 2016, there has been a steady rise in the number of permits issued, which surpassed 200 per year. Most of the permits were granted to IT specialists and engineers, followed by chief executives, managers, and experts.

As in Bulgaria, Ukrainian and Russian migrants are the main users of the Blue Card instrument in Poland with 3567 and 1037 permits issued, respectively. ${ }^{152}$ However, the overall number of permits issued in the period from 2012 to October 2019 was 7090, which significantly exceeds the number issued in Bulgaria for the same period. In 2016, the number of permits in Poland surpassed 1000 per year, reaching a peak of 2046 Blue Cards in 2018. According to the Foreigners' Office data from 2017, these migrants work mainly as legal, social, and cultural professionals, business and administration professionals, as well as in the IT sector. ${ }^{153}$

The focus groups conducted in Poland and Bulgaria included mainly migrant workers who were supported by the IT company's relocation manager in the application process for the Blue Card permit. But they were able to share the experiences of some of their colleagues who had to apply by themselves at some point in time. Most of the participants in Poland explained that they were given a choice between the national and the Blue Card permits, and that they were advised by the recruiting company to apply for the Blue Card permit. ${ }^{154}$ The rest had informed themselves about the advantages of the permit and even about the differences that existed among EU Member States.

The Blue Card permit appealed particularly to IT professionals because it was valid for 3 years and provided a period of 3 months to look for a new job in case of unemployment, compared to the 1 month allowed under the national permit in Poland. Furthermore, Blue Card holders' spouses were also entitled to the same duration of validity and allowed unrestricted access to the labour market without the need to apply for a work permit and free access to education for family members. Finally, this permit was part of the EU system, which offers the holder the

\footnotetext{
${ }^{150}$ The data refer to the number of permits and not to permit holders, which means that there could be more than one permit per person. The data were obtained from the Ministry of Interior in September 2019 with decision No 5364p151461/12 August 2019 of Migration Directorate of the Ministry of Interior.

${ }^{151}$ Ibid.

${ }^{152}$ The data were obtained from the Polish Office of Foreigners in October 2019.

${ }^{153}$ The data were obtained from the Polish Office of Foreigners in October 2017. Since 2018 the Polish administration no longer collects separate data on professions of the Blue Card holders.

${ }^{154}$ Focus groups with Blue Card holders from Russia, Ukraine and mixed group of Russian speakers, Poland, December 2016, Annex IV. Interview with business representatives, Poland, December 2016, Annex II.
} 
opportunity to work in other EU Member States where many IT companies often have other branches. ${ }^{155}$

All applicants in Poland first applied for a national visa type D to enter the country and initially stayed on the basis of this visa. Some indicated that they had to go through a 'probation period' and were not offered a labour contract until a few months after their arrival, which would allow them to submit an application for the Blue Card permit. ${ }^{156}$ According to focus group participants, it took 6 months on average from receiving the job offer to obtaining the Blue Card permit, including the 2-3 months (a maximum of up to 4 months) to receive the permit after the application.

Among the participants there were Blue Card holders who had received their permits in 2013 and considered themselves in the 'first wave'. ${ }^{157}$ In the beginning, they had experienced problems because the administration was still elaborating the application procedure and the relocation managers from the IT companies did not have experience handling the new system. For example, the first Blue Card holders had to go through an interview at the local authority while later applicants did not have to comply with such a requirement.

In Bulgaria, the application process initially took 7-8 months to complete, and at the time of the field research in September 2016, lasted on average 5-6 months. ${ }^{158}$ All of the foreigners interviewed had to apply for work authorisation while still in their country of origin and then for a visa on the basis of the obtained decision for work authorisation. In order to apply for a visa, they needed to present the work authorisation decision and evidence of possessing health insurance, but it was reported that the consuls often also required a rental contract - a requirement that Blue Card applicants are exempt from. The relocation manager had to call the embassies and explain to them what the legal provisions were for this group of migrant workers, including the fact that the deadline for issuing a visa type D for Blue Card holders was 15 working days. ${ }^{159}$ This period was not respected in practice and the visas took up to 30 days to issue. This caused delays in the already lengthy application process.

After arriving in Bulgaria, they had to first find an apartment because they needed a rental contract in order to be able to finalise the Blue Card permit application. ${ }^{160}$ During this period, which could take up to 1 month, they could not be officially employed and work because they first had to register their personal number that was

\footnotetext{
${ }^{155}$ Focus groups with Blue Card holders from Russia, Ukraine and mixed group of Russian speakers, Poland, December 2016, Annex IV.

${ }^{156}$ Focus group with Blue Card holders: mixed group of Russian speakers, Poland, December 2016, Annex IV.

${ }^{157}$ Focus groups with Blue Card holders: Ukrainian and mixed group of Russian speakers, Poland, December 2016, Annex IV.

${ }^{158}$ Focus group with Blue Card holders from Ukraine and Russia, Bulgaria, September 2016, Annex IV.

${ }^{159}$ Interview \#18 with representatives of an IT company, Bulgaria, September 2016, Annex III.

${ }^{160}$ Focus group with Blue Card holders from Russia, Bulgaria, September 2016, Annex IV.
} 
printed on the Blue Card in the National Revenue Agency. Only afterwards could the employer register the employment contract with the same agency so that the Blue Card holder was able to start working.

The main problems highlighted by the focus group participants with regards to the application procedure in both countries were caused by the requirement to prove that the foreigner had a higher professional qualification, either through the completion of (at least) a 3-year course of study at a higher education institution or through 5 years of professional experience in a field that was compatible with the profession. One of the focus group participants in Poland said that he decided to apply for a Blue Card permit through the procedure, taking into account his diploma because his education was directly related to the job position. ${ }^{161}$ However, because the translation of his diploma did not contain the same words as the job description, the officer did not accept his documents and he had to apply on the basis of his professional experience by translating his 'work book'. ${ }^{162}$

Other focus group participants shared that at first they did not know which documents would be considered as constituting solid proof so they would submit documents proving both their education and professional qualification(s). ${ }^{163}$ Another problem in this respect was caused by the nature of work of the IT specialists in Ukraine who very often work as sole traders/self-employed. ${ }^{164}$ This would prevent them from evidencing their professional experience, and if their diploma was not related to the job description in question, then their applications would be refused.

Currently, and in violation of the Blue Card Directive, applicants in Bulgaria are required to present both types of documents - diplomas and proof of professional experience. In addition, the provisions of the ALMLM do not specify how many years of experience are required and whether they need to be acquired while in the same position, which creates problems for the applicants and leaves a great deal of discretion in the hands of the administration. ${ }^{165}$

Other problems concerning the application process were related to the discretion of the regional authorities in Poland, which in turn led to the law being applied differently. The focus group participants shared that their company was well-known to the authorities and at the time of the data collection in late 2016, the procedure in Krakow was the fastest. ${ }^{166}$ In other Polish cities, the waiting period could take up to 9 months, even though most of the Blue Card permits were issued in Krakow. ${ }^{167}$ The representatives of the IT company's management who were interviewed shared that

\footnotetext{
${ }^{161}$ Focus group with Blue Card holders: mixed group of Russian speakers, Poland, December 2016, Annex IV.

${ }^{162}$ According to one of the respondents: "Work book" in Russia is the official CV from the Russian employer. It comes from the Soviet Union'. From focus group with Blue Card holders: mixed group of Russian speakers, Poland, December 2016.

${ }^{163}$ Focus group with Blue Card holders from Ukraine, Poland, December 2016, Annex IV.

${ }^{164}$ Focus group with Blue Card holders from Ukraine, Poland, December 2016, Annex IV.

${ }^{165}$ Interview \#20 with representatives of an IT company, Bulgaria, December 2016, Annex III.

${ }^{166}$ Focus group with Blue Card holders from Ukraine, Poland, December 2016, Annex IV.

${ }^{167}$ Focus group with Blue Card holders from Ukraine, Poland, December 2016, Annex IV.
} 
they had experienced some problems with the issuing of the Blue Card permits for their employees in other cities where the company had a branch, and had to intervene and explain the regulations to the officials. For instance, in order to issue a (dependent) permit for the family member of a Blue Card holder, the authorities in one town required that the Ukrainian marriage certificate had to be recognised under Polish law; the IT company representatives stressed that this was not an explicit legal requirement. ${ }^{168}$ By way of contrast, the authorities in Warsaw merely required a sworn translation of the marriage and birth certificates, respectively. There were also regional differences regarding the recognition of diplomas: some governors required confirmation by the Ministry of Science and Higher Education while others did not.

According to the IT company management representatives, the Polish officials did not always know the legislation in question and were afraid to issue the Blue Cards because they gave too many rights to foreigners and had to stay restrictive. ${ }^{169}$ Therefore, the company's approach was 'to fix structural issues, not to survive' ${ }^{170}$ Due to the lack of IT specialists in the Polish labour market, they pursued an active recruitment strategy and supported, both financially and logistically, their employees throughout the Blue Card permit application process. Part of their approach was to work with local authorities in order to share their best practices concerning the application of the legislation and explain how the Blue Card Directive provisions were supposed to work in practice. ${ }^{171}$ They emphasised that the problems with the implementation of the Blue Card Directive in Poland and different authorities' broad discretion was due to the lack of a precise formulation of the requirements for granting a Blue Card permit. For instance, with regards to the qualifications, the Polish legislation was silent on what constituted professional experience; in locations where the administration did not have any experience, they did not know how to interpret this kind of provision, which consequently led to lengthy delays in the application process. ${ }^{172}$

For the representatives of the IT business in Bulgaria, one of the biggest problems was the labour market test as part of the Blue Card application that they were still required to perform at the time of the interview in 2016. They referred to it as an 'absolute deception'. ${ }^{173}$ According to the interviewees, it was a redundant and formal procedure that always ended with a negative result and which led to the recruitment of a third-country candidate who had already been selected. They also said that the Labour Office officials supported them throughout this procedure because they also knew that the Bulgarian labour market lacked these types of

\footnotetext{
${ }^{168}$ Interview \#22 with IT business management representatives, Poland, December 2016, Annex II.

${ }^{169}$ Interview \#22 with IT business management representatives, Poland, December 2016, Annex II.

${ }^{170}$ Interview \#22 with IT business management representatives, Poland, December 2016, Annex II.

${ }^{171}$ Interview \#22 with IT business management representatives, Poland, December 2016, Annex II.

${ }^{172}$ Interview \#22 with IT business management representatives, Poland, December 2016, Annex II.

${ }^{173}$ Interview \#18 with representatives of an IT company, Bulgaria, September 2016, Annex III.
} 
specialists and there were no other candidates that they could offer to the IT business. ${ }^{174}$

When asked whether they had returned to their countries of origin for work, the focus group participants in Poland and Bulgaria answering in the affirmative said that they did so mainly through the internal 'home office' system that the company offered through its network of branches in the region or simply went on business trips. ${ }^{175}$ This type of circulation did not create any problems in relation to visas and taxation.

The interviewed Russians in both Bulgaria and Poland were not interested in returning to Russia, mainly due to political reasons. ${ }^{176}$ Some shared that they feared for their safety, while others stated that they might get into trouble because of the applicable Russian laws on currency and tax. The Russian focus group participants also shared that it did not make much sense for them to go back home for work because their labour contracts and permits were only for 1 year and subject to renewal. In addition, most of the circulation of the Ukrainian Blue Card holders was due to personal reasons but not done very often because of the long queues at the border with Ukraine. ${ }^{177}$ In two cases, the wives of the Blue Card holders went back and spent up to 6 months in their country of origin.

The IT company management representatives in Poland shared that they were also not interested in having their employees circulating: 'We don't need people to come here and work for only six or nine months. The key of our business is longterm engagement' ${ }^{178}$ However, they stressed that there were companies that focused mainly on short-term projects and which could benefit from this type of mobility. In general, they stated that what was needed was 'a more flexible idea of movement'.

\subsubsection{Seasonal Workers' Directive}

The Act of 20 April 2004 on Promotion of Employment and Labour Market Institutions was amended on 1 January 2018 in order to implement the Seasonal Workers Directive ${ }^{179}$ into Polish law and reform the Oświadczenie procedure. ${ }^{180}$ The Polish seasonal work permit is issued on the basis of Article 88 (2) when foreigners perform work in the scope of activities specified in the Regulation of the Minister of

\footnotetext{
${ }^{174}$ Interview \#18 with representatives of an IT company, Bulgaria, September 2016, Annex III.

${ }^{175}$ Focus group with Blue Card holders from Ukraine, Bulgaria, September 2016, Annex IV. Focus group with Blue Card holders from Ukraine, Poland, December 2016, Annex IV.

${ }^{176}$ Focus group with Blue Card holders from Russia, Bulgaria, September 2016, Annex IV. Focus group with Blue Card holders from Russia, Poland, November 2016, Annex IV.

${ }^{177}$ Focus group with Blue Card holders from Ukraine, Poland, December 2016, Annex IV.

${ }^{178}$ Interview \#22 with IT business management representatives, Poland, December 2016, Annex II.

${ }^{179}$ Directive 2014/36/EU of the European Parliament and of the Council of 26 February 2014 on the conditions of entry and stay of third-country nationals for the purpose of employment as seasonal workers [2014] OJ L 94.
}

${ }^{180} \mathrm{OECD}$ (2018), p. 264. 
Family, Labour and Social Policy of the 8 of December $2018^{181}$ on the basis of contracts with entities whose registered offices or places of residence are located on the territory of Poland. The activities stipulated in this Regulation are agriculture, forestry, fishery, services, gastronomy, and hospitality related to tourism, such as shortterm accommodation, camping sites, and mobile catering establishments. In line with the Seasonal Workers' Directive, this temporary permit is only issued for up to 9 months in a single calendar year.

The personal scope of the Seasonal Workers' Directive is limited to those workers who apply to be admitted to the EU from a third country ${ }^{182}$ as well as those who have already been admitted under the terms of this EU instrument (Article 2 (1) of the Directive). However, as Peers stressed, the Directive does not explicitly ban Member States from considering in-country applications, and according to Recital 18 of its Preamble, it does not affect the right of legally resident third-country nationals to work. ${ }^{183}$ Such applications, however, would fall outside the scope of the Directive. ${ }^{184}$

Polish law has used the fact that in-country applications are not explicitly banned by the Directive and has introduced two separate procedures for issuing a seasonal work permit depending on where foreigners are located at the time of application abroad or in Poland. In the first case, referred to as the 'foreign (Zagraniczna) path', when foreigners apply for a visa for the purpose of performing seasonal work ${ }^{185}$ or enter Poland on the basis of a visa-free regime, the employer submits an application to a relevant local governor, who enters the application into a seasonal work application registry and issues a certificate of entry within 7 to 30 days (see Article 88p of the AEPLMI). This certificate serves as the basis for the visa application and entry as part of the visa-free regime. A seasonal work permit is issued after the foreigner's entry and upon presentation of documents authorising the foreigner to stay in Poland, and the address of accommodation during the stay in Poland. In the second case, referred to as the 'national path', when the foreigner is staying in Poland on grounds which allow for a work permit application, the employer submits it and the local governor renders a decision within 7-30 days (Article 88pa of the AEPLMI).

According to Article 88o (1) of the Polish Act of 20 April 2004 on Promotion of Employment and Labour Market Institutions, a seasonal work permit is issued when

\footnotetext{
${ }^{181}$ Regulation of the Minister of Family, Labor and Social Policy of 8 December 2018 regarding activity subclasses according to the Polish Classification of Activities (PKD), in which seasonal work permits for a foreigner are issued/Rozporządzenie Ministra Rodziny, Pracy i Polityki Społecznej z dnia 7 września 2018 r. zmieniające rozporządzenie w sprawie podklas działalności według Polskiej Klasyfikacji Działalności (PKD), w których wydawane są zezwolenia na pracę sezonową cudzoziemca (Dziennik Ustaw z 2018 r., poz. 1749).

${ }^{182}$ See also Recital 15 in the Preamble saying that applications should only be made outside of the EU.

${ }^{183}$ Peers (2016), p. 384/ (footnote 546).

${ }^{184}$ Ibid.

${ }^{185}$ In line with Article 60 (1) 5a AF.
} 
the remuneration stated in the contract between the foreigner and the employer is not lower than the remuneration of employees working for the same number of hours, performing a job of a similar type, or working in a comparable position; it also requires that the employer has attached the negative results of a labour market test issued by the local governor as part of the application. The labour market test is not required for citizens of Armenia, Belarus, Georgia, Moldova, Russia, or Ukraine (Article 80o (2) of the AEPLMI) or when the foreigner had stayed uninterruptedly in Poland for a period of 3 years preceding the application (Article 88c (8) 2 of the AEPLMI). In addition, this document is waived for foreigners who graduated from a university located within the territory of Poland, other EEA country or the Swiss Confederation within the 3 years preceding the application for the issue of a work permit, or participating in doctoral studies taking place in Poland (Article 88c (8) 1 of the AEPLMI).

The Bulgarian Act on Foreigners introduced two authorisation regimes for seasonal workers: seasonal work for up to 90 days on the basis of a short-term visa type $C^{186}$ (Article 24 л (1) of the AFRB) and seasonal work permit for no less than 90 days and no more than 9 months (Article 24K of the AFRB). The Minister of Labour and Social Policy approves a List of the economic sectors, including activities, whose implementation depends on the change of seasons. This List is drawn up after consultations with the National Council for Labour Migration and Labour Mobility (Article 25 (2) of the ALMLM), and currently covers two sectors: agriculture, forestry and fisheries; and, hotels and restaurants. ${ }^{187}$

In order to carry out seasonal work for up to 90 days, foreigners must have a valid visa type $C$ for the purposes of seasonal work, where this is required, and the employment must be registered by the Employment Agency on the basis of a declaration submitted by the employer in line with the ALMLM and its Implementing Regulation (Article 24л (1) of the AFRB). In line with Article 20 of the Directive, the employer is obliged to submit evidence to the Employment Agency that the seasonal worker will be provided with appropriate accommodation, and that the health and safety requirements have been fulfilled (Article 28 of the ALMLM).

In addition, as part of the application process, the employer needs to attach a declaration stating that the work offered and the pay conditions are no less favourable than the conditions offered to Bulgarian citizens in the respective labour category (Article 32 (1) 2 in conjunction with Article 2 (1) 7 of the Implementing Regulation of the ALMLM); other required documents include a copy of the labour contract, stating amongst other things, that the transport costs and the compulsory health and social security insurance of the seasonal workers shall be borne by the employer (Article 27 (1) and (2) of the ALMLM in conjunction with Article 2 (1) 9 of the Implementing Regulation of the ALMLM). Seasonal workers coming initially for a period of up to 90 days may extend their work stay with a seasonal worker permit under Article 24 (1) of the ALMLM for up to 9 months within the

\footnotetext{
${ }^{186}$ In case a visa is required.

${ }^{187}$ Adopted by Order РД-01-47 /17 January 2017 of MLSP.
} 
calendar year, starting from the date of initial registration of the employment (Article 29a (1) of the ALMLM). They are exempted from the requirement to apply for access to the Bulgarian labour market while residing outside the territory of the country (Article 5 (2) of the ALMLM). ${ }^{188}$ However, they still need to apply for visa $\mathrm{D}$, which means that in practice they have to leave the territory of Bulgaria.

In Bulgaria the 'seasonal worker permit' granting the right to continuous residence can be obtained by foreigners who meet the requirements for access to the labour market in accordance with the ALMLM ${ }^{189}$ and who have obtained a visa type D (Article 24K (1) of the AFRB). The permit for a seasonal worker is issued upon the submission of a single application and after a positive decision has been taken by the Employment Agency. It covers the duration of the labour contract, which must be for no less than 90 days and no more than 9 months (Article 24k (2) of the AFRB). The Employment Agency issues the work authorisation decision, which forms part of the permit for the seasonal worker issued by the Ministry of Interior, within 10 days after an employer submits an application (Article 24, Para 1 (2) of the ALMLM).

With regards to circular migration facilitation, foreigners who performed work in Poland at least once in the 5 years preceding the seasonal work permit application are treated with priority when considering seasonal work permit applications, if the work will be performed on the basis of an employment contract (Article 88p (2) of the AEPLMI). In addition, Article 88q allows for seasonal multi-annual work permit applications at the request of employers for periods of up to 9 months during a calendar year falling within no more than three subsequent calendar years, when the workers are citizens of Armenia, Belarus, Georgia, Moldova, Russia, or Ukraine, have worked at least once for the employer in the period of 5 years preceding the date of the application, and the employer is not in arrears with payment of income tax advances and social security contributions (if such were required).

The Bulgarian Act on Foreigners states that the seasonal worker permit is issued on the basis of an accelerated procedure for those candidates who have worked in Bulgaria at least once as a seasonal worker at any point during the preceding 5 years (Article 24k (4) of the AFRB). This accelerated procedure was detailed on the basis of the amendments of the Implementing regulation of the ALMLM in 2018, which provided that work authorisation decisions for such seasonal workers who have already worked in Bulgaria must be issued within 10 days after an employer has submitted an application (Article 20a (1)). In addition, there is no labour market test requirement as part of the accelerated procedure (Article 20a (2) of the Implementing regulation of the ALMLM). Compared to the regular procedures for seasonal work for up to 90 days and seasonal work for no less than 90 days and no more than 9 months, this accelerated procedure does not provide any additional facilitation as

\footnotetext{
${ }^{188}$ For more details, see Article 21a of the Implementing Regulation of the ALMLM.

${ }^{189}$ Having been offered work and salary conditions that are not less favourable than the conditions offered to Bulgarian citizens in the respective labour category, possessing specialised knowledge, skills and professional experience that is required for the post in question in line with Article 7 (1) 3 and 4 of the ALMLM.
} 
the regular procedure does not require a labour market test either. In both cases, the work authorisation must be issued within 90 days after an employer has submitted an application (see Article 24 (2) of the ALMLM and Article 32 (3) of Implementing regulation of the ALMLM).

As a result of the lobbying efforts of Bulgarian employers working in the ambit of tourism, the Implementing Regulation of the ALMLM was amended in June 2017 to facilitate the recruitment of foreigners to carry out seasonal work for up to 90 days. ${ }^{190}$ The amendments stipulated that no labour market test is to be applied for this category of workers (Article 32 (1) 2 and (2) of Implementing Regulation of ALMLM) and that employers were not required to submit documents proving the education and experience of these categories of workers in line with the general application for access to the Bulgarian labour market (Article 32 (1) 2 of the Implementing Regulation of ALMLM). The labour market test was also waived for seasonal workers staying for a period of up to 9 months (Article 25 (4) the Implementing Regulation of ALMLM). ${ }^{191}$

\subsubsection{Seasonal Workers' Directive - Implementation Dynamics}

According to data obtained by the Bulgarian Employment Agency, the number of third-country nationals registered in the country for the purpose of exercising seasonal work for up to 90 days (in line with Article 24л of the AFRB) is rising ехроnentially. ${ }^{192}$ Starting at 612 declarations in 2017, the registrations surpassed 2000 in 2018 and reached 2579 in the first half of $2019 .{ }^{193}$ Most of these seasonal workers who came for up to 90 days were from Ukraine. By contrast, the number of seasonal work permits (in line with Article $24 \mathrm{k}$ of the AFRB) continues to be rather low. ${ }^{194}$ According to data of the Ministry of Interior, in the period between 2017 and first half of 2019, a total of 162 such work permits were issued. ${ }^{195}$ However, when compared to data for the same period obtained from the Employment Agency, this number is much higher - almost 900 seasonal work permits, which is more likely to be

\footnotetext{
${ }^{190}$ SG No. 48/16 June 2017, Para 5.

${ }^{191}$ The labour market test exemption for this category of seasonal workers is still not correctly detailed in the Implementing Regulation of ALMLM. It was amended with SG No. 43/ 25 May 2018. It needs to be stressed, however, that the new Article 20a (2) of the Implementing Regulation of ALMLM refers only to the accelerated procedure under Article 24 (4) ALMLM. Nonetheless, the Bulgarian administration is using this provision to waive the labour market exemption as part of the application procedure. Official response to an official request for information to the Employment Agency, Reg. No 10-00-16405-1/6 January 2020.

${ }^{192}$ Data obtained from the Employment Agency in September 2019.

${ }^{193}$ Ibid.

${ }^{194}$ Data obtained from the Employment Agency and the Ministry of Interior in September 2019.

${ }^{195}$ Ibid.
} 
the correct number. ${ }^{196}$ Here again Ukrainians are in the lead, followed by Kyrgyz and Turkish workers.

In Poland, in 2018 a total of 121,436 seasonal work permits were issued as a result of 235,294 applications for seasonal work permits that were submitted at the Local Labour Offices. This number includes 138,344 seasonal work certificates issued to foreigners staying outside Poland to enable them to apply for visas using the 'foreign path'. ${ }^{197}$ These numbers have increased already in the first half of 2019 , with 137,266 certificates and 70,027 work permits. Ukrainians, followed by Belarusians and Moldovans, dominate the seasonal work permits. ${ }^{198}$ When it comes to seasonal work certificates, Ukrainians are in the lead, followed by Belarusian and Nepalese workers.

Poland's significant delay in transposing the Seasonal Workers' Directive, which came into force in early 2018, did not allow for empirical data collection as part of this study in order to capture the implementation of this instrument. ${ }^{199}$ Nevertheless, since this is one of EU's legal instruments explicitly aimed at fostering circular migration, and in order to be able to compare it with the Bulgarian case, it was necessary to consider it in this chapter. Therefore, the study's research design initially envisaged only focus groups with seasonal workers in the Bulgarian tourism sector. However, during the recruitment phase in the summer of 2016, the study's informants shared that these migrants were entering on a tourist visa and, in general, worked irregularly. Interviewed tourism industry representatives later confirmed this information, which posed challenges with regards to the ethical standards employed by the study, which leave irregular migrants outside the scope of this research. ${ }^{200}$

Furthermore, the transposition of the Seasonal Workers' Directive allegedly did not lead to regularisation of this type of work in Bulgaria in the 2016/2017-winter season. Numerous media outlets reported that the Labour Inspectorate had found that Ukrainian and Moldovan workers were coming to Bulgaria as trainees under concluded exchange agreements between professional schools in the Eastern Partnership countries and tourist companies in Bulgaria; in reality, they were working full-time and receiving salaries without having proper labour contracts. ${ }^{201}$

To compensate for this empirical gap and provide more information on the implementation of this Directive in Bulgaria, two interviews with a representative of an employers' organisation in the Bulgarian tourism sector were conducted in

\footnotetext{
${ }^{196}$ Data obtained from the Employment Agency and the Ministry of Interior in September 2019.

${ }^{197}$ Ministry of Family, Labour and Social Policy, Foreigner's seasonal work permits: https://psz. praca.gov.pl/web/urzad-pracy/-/8180228-zezwolenia-na-prace-sezonowa-cudzoziemca Accessed 21 December 2019.

${ }^{198}$ Ibid.

${ }^{199}$ The transposition deadline was 30 September 2016.

${ }^{200}$ For more details, see Chap. 2, Sect. 2.3 .

${ }^{201}$ Offnews (2017); Dnevnik (2017).
} 
January and October 2017, and one with a recruiter in October 2017..$^{202}$ The representative of the employers' organisation stressed that Bulgaria needed seasonal workers from third countries because Bulgarians who once worked in this sector had left for other Member States. In January 2017, the interviewee said that he appreciated the measure of 'lifting of the restrictions' for hiring third-country nationals but complained that the procedure developed under the ALMLM was cumbersome and designed to purposefully create obstacles for the recruitment of migrant workers. ${ }^{203}$

The interviewee expressed his dissatisfaction with the provisions adopted and which stipulated two different procedures for seasonal work: up to 90 days and between 90 days and 9 months in line with the Seasonal Workers' Directive. He said that the authorisation of 90 days was insufficient for the needs of the tourism industry because employers needed time to train the workers and wanted them to stay during the whole summer season, which is 6 months. However, the procedure concerning seasonal work permits for up to 9 months was too expensive given the number of workers that the hotels had to recruit: up to 400 EUR per person for the visa and work permit application ${ }^{204}$ compared to 35 EUR for workers coming for up to 90 days, ${ }^{205}$ and even less after the visa liberalisation with Ukraine came into force. ${ }^{206}$ The respondent claimed that the Black Sea resort, where his business operated, alone needed 15,000 workers in 2017 and that it was impossible to afford the expenses stemming from seasonal work permits. The data on permits presented above as well as research conducted in the summer of 2019 demonstrate that this trend persists and that employers consequently still prefer to recruit seasonal workers on the basis of the procedure for up to 90 days. ${ }^{207}$

Therefore, according to the follow-up interviews in 2017 and data collected in 2019, the tourism sector primarily hired students from Ukraine and Moldova because this was cheaper in comparison to other countries of origin due to the visa conditions and geographic proximity. ${ }^{208}$ They worked for 90 days and were replaced by a second wave of seasonal workers also hired for 90 days in order to cover the

\footnotetext{
${ }^{202}$ Interview \#11 with representative of an employers' organisation in the tourism sector, Bulgaria, January 2017, Annex III.

${ }^{203}$ Interview \#11 with representative of an employers' organisation in the tourism sector, Bulgaria, January 2017, Annex III.

${ }^{204}$ Interview \#22 with representative of an employers' organisation in the tourism sector, Bulgaria, October 2017, Annex III. The costs are for the work permit fee (currently 50 EUR), translation and legalisation of documents, transport, and the fee for the recruitment agency. In general, the visa fees are paid by migrant workers.

${ }^{205}$ Interview \#11 with representative of an employers' organisation in the tourism sector, Bulgaria, January 2017, Annex III.

${ }^{206}$ Interview \#22 with representative of an employers' organisation in the tourism sector, Bulgaria, October 2017, Annex III.

${ }^{207}$ Vankova and Ivanova (forthcoming).

${ }^{208}$ Interview \#22 with representative of an employers' organisation in the tourism sector, Bulgaria, October 2017, Annex III.
} 
rest of the summer season. ${ }^{209}$ The recruiter interviewed in October 2017 emphasised that the cumbersome procedure for hiring seasonal workers, which caused delays at the beginning of the summer season, improved following the amendment of the Implementing Regulation of the ALMLM in 16 June 2017. These amendments were engendered as a result of petitions by different stakeholders to the administration.

The persistent problems were related to the documents required for the application for seasonal work permits for up to 9 months. The documents for the applicant's experience and qualifications had to be legalised in line with Article 4 (3) 1 of the Implementing Regulation of the ALMLM, which further added to the expenses that employers incurred in order to hire such workers. Seasonal workers who wanted to extend their stay from 90 days to 9 months faced the same hurdle, as they also needed to present the above-mentioned documents. Another problem was posed by the requirement to demonstrate experience, even for entry-level positions, such as an assistant cook, which was impossible in the majority of cases. In addition, according to the interviewee, it 'makes no sense' to require migrants to apply for work permits when they are outside Bulgaria. ${ }^{210}$

At time of writing, there was still no comprehensive study of the implementation of the Seasonal Workers' Directive in Poland. A 2019 report on seasonal workers entering through both the Oświadczenie procedure and on the basis of seasonal temporary work permits demonstrates that Poland is attractive to migrants due to, amongst other things, the possibility of legal employment and considered as offering 'the easiest option' when it comes to application documents. ${ }^{211}$ It should be borne in mind, however, that these migrants were assisted by an intermediary agency, which facilitated the application process.

\subsubsection{EU Long-Term Residence Directive}

In line with this study's research design, the provisions of the EU Long-term Residence Directive ${ }^{212}$ allowing individuals to be absent from the territory of the host Member State are presented in this section. As already mentioned, the European Commission planned to use these provisions as an instrument that could facilitate circular migration. ${ }^{213}$

The EU Long-term Residence Directive was transposed into Polish law via Chapter VI of the Polish Act on Foreigners. According to its Article 215 (1), an EU

\footnotetext{
${ }^{209}$ Interview \#22 with representative of an employers' organisation in the tourism sector, Bulgaria, October 2017. Interview \# 23 with seasonal workers recruiter in the tourism sector, Bulgaria, October 2017, Annex III.

${ }^{210}$ Interview \#23 with seasonal workers recruiter in the tourism sector, Bulgaria, October 2017, Annex III.

${ }^{211}$ Pawlak and Lashchuk (forthcoming).

${ }^{212}$ Council Directive 2003/109/ECof 25 November 2003 concerning the status of third-country nationals who are long-term residents [2004] OJ L 16.

${ }^{213}$ See Chap. 3, Sects. 3.2 and 3.4 for more details.
} 
long-term residence permit is revoked when the holder leaves the territory of Poland for a period longer than 6 years or where the holder has left the territory of the EU for a period of 12 consecutive months. The Act does not allow for longer periods of absence for specific or exceptional reasons in line with Article 9 (1) (c) of the Directive.

Article 40 (1) 6 of the Bulgarian Act on Foreigners stipulates that foreigners lose their EU long-term residence permit or national permanent residence if they are absent from the territory of Bulgaria for 12 consecutive months unless they have permits based on one of the investment grounds contained in Article 25 of the AFRB. Similar to the provisions of Polish law, according to Article 40 (4) of the Bulgarian Act on Foreigners, the permit will also be revoked in cases where the individual is absent from the territory of Bulgaria for a total period of 6 years.

\subsubsection{EU Long-Term Residence Directive - Implementation Dynamics}

Between 2011 and mid-2019, 2420 third-country nationals obtained EU long-term residence permits in Bulgaria (under Article $24 \Gamma$ (1) of the AFRB). By contrast, 33,814 national permanent residence permits have been issued in the same period (in line with Article 25 (1) of the AFRB). ${ }^{214}$ According to Bulgarian Ministry of Interior data, so far only two EU long-term residence permits were revoked during this period because of absences of up to 12 consecutive months (on the basis of Article 40 (1) 6 of the AFRB). In addition, no EU long-term residence permits have been rescinded on the basis of absence of up to 24 months in the case of former Blue Card holders (on the basis of Article 40 (1) 11 of the AFRB) or after a 6-year-long absence from the territory of Bulgaria (Article 40 (4) of the AFRB).

The data support the findings from the focus groups that migrant workers in Bulgaria are generally interested in achieving and keeping a secure status and not in engaging in voluntary circular migration due to risks of losing their permits. None of the interviewed EU long-term residence or national permanent residence permit holders were interested in circulation for work. In addition, at the time of the focus groups, none of the Blue Card holders in Bulgaria had stayed for more than 5 years to become eligible to apply for an EU long-term residence permit. However, judging by their attitudes toward their countries of origin, they were not planning to engage in work-related circulation outside the possibilities for business or 'home office' trips.

By way of comparison, in the same period, 13,931 EU long-term residence permits and 76,616 permanent residence permits were issued in Poland. ${ }^{215}$ Nineteen permanent residence permits and $10 \mathrm{EU}$ long-term residence permits have been revoked.

\footnotetext{
${ }^{214}$ Data obtained from the Ministry of Interior in September 2019. Despite the fact that the reference period of the official request for information filed was 2007-2019, the Ministry provided data only from 2011 onwards because this is when Article $24 \Gamma$ was introduced in the AFRB.

${ }^{215}$ Data obtained from the Polish Office of Foreigners in October 2019.
} 
During the recruitment phase for the focus groups, it was impossible to find Ukrainians and Russians who had obtained the EU long-term residence permit and were also engaged in circular movement between Poland and their country of origin. Only one participant had a circular migration trajectory, but this was before she had been granted the permit. She explained that she deliberately decided to retain her Ukrainian citizenship so she would have the possibility of moving between her country and Poland in the future. ${ }^{216}$ The participant shared that, after 20 years, she still missed her country and would have liked to be able to spend some time there, but at the same time she had her place to live in Poland and 'a fundament to rely on - employment opportunities, my friends' ${ }^{217}$ Asked whether she was aware that she could lose her permit if she stayed longer than the allowed absence, she replied in the negative. This finding is in line with the latest Implementation Report of the European Commission underscoring that there was a general lack of information available about the EU long-term residence status among both migrants and national administrations. $^{218}$

The data on permits, analysed together with the findings of the focus groups, shows that the EU long-term residence permits generally are not used for circular migration purposes.

\subsubsection{Labour Migration Directives Containing Circular Migration Elements and their Implementation Dynamics}

\subsubsection{Intra-corporate Transferees' Directive}

The Act of 24 November 2017 amending the Act on Foreigners and Certain Other Acts also introduced the Intra-corporate Transferees' Directive ${ }^{219}$ into Polish law, which entered into force in early $2018 .{ }^{220}$ When submitting this permit application, the foreigner must be outside the territory of the EU Member States, unless that person seeks subsequent permit extension for the purpose of work under an intracorporate transfer. A temporary residence permit for the purpose of work as part of an intra-corporate transfer is granted when, amongst others things, applicants meet the requirements concerning professional qualifications, health insurance,

\footnotetext{
${ }^{216}$ Focus groups with Ukrainian migrants, Poland, November 2016, Annex IV.

${ }^{217}$ Focus groups with Russian migrants, Poland, November 2016, Annex IV.

${ }^{218}$ European Commission (2019b), p. 1, p. 9.

${ }^{219}$ Directive 2014/66/EU of the European Parliament and of the Council of 15 May 2014 on the conditions of entry and residence of third-country nationals in the framework of an intra-corporate transfer [2014] OJ L 157.

${ }^{220}$ The Act of 22 February 2019 amending the Act on Foreigners and Certain Other Acts/ Ustawa z dnia 22 lutego 2019 r. o zmianie ustawy o cudzoziemcach oraz niektórych innych ustaw (Dziennik Ustaw z 2019 r., poz. 577). The amendment to the Act on Foreigners entered into force on 12 February 2018.
} 
accommodation, as well as previous employment at the same enterprise in line with the Directive's provisions and possibility to transfer back to it after the stay in Poland (Article 139 of the AF). In addition, applicants need to have a contract or document specifying the period of their transfer within the enterprise, the seat of the host entity, their position in the receiving unit, remuneration, ${ }^{221}$ and other employment conditions in the host entity.

According to Article 33ח (1), foreigners can obtain a 'permit for persons transferred through intra-corporate transfer' in Bulgaria, thereby granting them the right to continuous residence so long as they meet the requirements for access to the labour market under the provisions of the ALMLM and if they possess a visa type D in accordance with Article 15 (1) of the AFRB. As in Poland, applicants need to present evidence that they have met the requirements of the Directive (Article 23 of the Implementing Regulation of the ALMLM). The employer is exempted from performing a labour market test and from complying with the 20/35\% cap requirement with regards to ICT applicants (Article 31 (2) of the ALMLM). If the duration of the employment contract is less than 1 year, the permit will be issued for the duration of the employment contract (Article 33ח (2) of the AFRB).

In line with Article 139b (1) of the Polish Act on Foreigners by way of a ministerial regulation, the first ICT permits granted in a given calendar year might be capped in terms of specific provinces, professions, or types of activities of the host entities. The permit may be issued for a maximum period of 3 years for managers and specialists, and 1 year for employees in training. Poland does not impose the so-called cooling off period provided for in Article 12 (2) of the Directive after the maximum period of stay has been reached, which means that ICTs can choose to circulate between Poland and their home country without the need to wait for up to 6 months before they can engage in a new transfer.

This permit is issued for a period of 1 year by the Bulgarian Ministry of Interior following a positive decision by the Employment Agency based on a single permit procedure and it can be renewed if the circumstances for its issuance have not changed. Third-country nationals can work in Bulgaria on a continuous residence permit for an intra-corporate transfer for a period of up to 3 years as employees who are managers and specialists and 1 year for trainee employees (Article 32 (2) of the ALMLM). A new work authorisation application can only be submitted after a 6-month interruption between the expiration of a third-country national's permit

\footnotetext{
${ }^{221}$ The remuneration needs to be: 1) higher than the income authorizing cash benefits from social security, mentioned in the Act of 12 March 2004 on social assistance with regard to the foreigner and each family member being subsisted by them (should exceed PLN 528 for people in the family or PLN 701 for single people);

2) Not lower than the remuneration of employees performing work comparable in type or on comparable position on the territory of the Republic of Poland in comparable working time;

3) Not lower than $70 \%$ of the average gross monthly remuneration in the national economy in the province in which host unit has the registered office, in the year preceding submission of the application for the permission; announced by the President of the Central Statistical Office on the basis of Article 30 (2) of the Act of 26 October 1995 on some forms of supporting residential construction.
} 
and the request for a new starting period of employment (Article 32 (2) of ALMLM), which could hinder circular migration.

\subsubsection{Intra-corporate Transferees' Directive - Implementation Dynamics}

Data retrieved from the national authorities of Bulgaria and Poland demonstrate that this instrument has hardly been used. In Bulgaria, in the period 2016 to mid-2019, only 60 ICT permits were issued, ${ }^{222}$ in Poland, from 2018 until mid-2019, only three were issued. ${ }^{223}$ Due to the late implementation of this Directive in Polish law, the operation of this instrument could not be captured through the collection of empirical data. However, the interviews conducted in Bulgaria with representatives from the IT sector - one before the adoption of the Implementing Regulation of the ALMLM and one after - shed light on the challenges faced in relation to the implementation of this instrument.

It became clear from the interviews with representatives of the Bulgarian IT sector that the ICT Directive did not suit their business needs and they had decided to quit using this instrument. ${ }^{224}$ The interviewees shared that they used this procedure when they started to develop the company a few years ago, but remarked that it 'turned out ineffective' due to the transfer extension conditions after the authorised 3-year period under the Directive had elapsed. ${ }^{225}$ The fact that the worker needed to wait for 6 months before re-applying for such transfer rendered this procedure ineffective for the IT business. Initially, when the Directive was transposed into Bulgarian legislation, the waiting period had been 3 months. ${ }^{226}$ The interviewees shared that this requirement not only interrupted the company's business and economic activities, but also the private lives of their employees:

'These people rent flats, buy mobile phones, buy cars, there are also procedures (...) Most of them are with their families, the children go to school and after the three-year period not only the person but also his family must leave the territory of Bulgaria and this child, being in school during the school year, should just leave and spend the remaining nine months in another school in his country. ${ }^{227}$

The requirement for work experience of up to 1 year in the main company from which the worker was transferred also posed certain challenges. In addition, the longer deadlines for issuing work authorisation - 30 working days compared to 15

\footnotetext{
${ }^{222}$ Data obtained from the Ministry of Interior in September 2019 with Decision No. 5364p151461/12 August 2019 of Migration Directorate of the Ministry of Interior.

${ }^{223}$ Data obtained from the Polish Office of Foreigners in October 2019.

${ }^{224}$ Interview \#18 with representatives of an IT company, Bulgaria, September 2016, Annex III.

${ }^{225}$ Interview \#18 with representatives of an IT company, Bulgaria, September 2016, Annex III.

${ }^{226}$ Interview \#20 with representatives of an IT company, Bulgaria, December 2016, Annex III.

${ }^{227}$ Interview \#18 with representatives of an IT company, Bulgaria, September 2016, Annex III.
} 
working days within the Blue Card procedure - was considered impractical. ${ }^{228}$ Finally, there was 'legal nonsense' that discouraged the company from using this instrument:

\begin{abstract}
'If a work authorisation is issued for instance on 1st of March, it becomes effective on 1st of March, the day of its issue. The applicant must submit application for visa type D with this work authorisation at the Bulgarian embassy in the country where he resides. The administrative period for issuing such a visa, which is for an intra-corporate transfer, is 30 working days. You can calculate by yourself, that it is about two months or 45 calendar days. But at this point, while I am waiting for this visa (and I will just add that they are never ready on time, so it generally takes about two months), the worker's work authorisation is elapsing and he has no right to be in the country. He is waiting for his visa in his country, he has no right to come, but his work authorisation has been issued and it needs to be issued as a required document in order to apply for a visa. This is a legal nonsense! As soon as this person receives his visa and has the right to come to the country legally, two months from his work authorisation has already expired (...). It is issued for one year, but when he comes here, he works only ten months, because in reality he was waiting for two months for a visa while there was an active work authorisation during that time. This is another signal that this procedure is not practical for us. ${ }^{229}$
\end{abstract}

\title{
6.3.4.3 Students' and Researchers' Directive
}

At the time of empirical data collection in the period 2016-2017, Poland had still not implemented the new Students' and Researchers' Directive. ${ }^{230}$ Directive 2005/71/EC was transposed through the Act on Amendment to the Act on Foreigners and Certain Other Acts of 24 May 2007, but its full implementation did not come about until the entry into force of the Act on Foreigners of 2013 in May 2014. The application procedure required foreigners to apply in person ${ }^{231}$ and present agreements that have been concluded with research institutions in Poland admitting them to conduct research projects. ${ }^{232}$ In addition, researchers also had to present a written declaration completed by the research organisation in which it committed to covering the cost of the researchers' stay in Poland as well as the costs of executing an eventual return order issued to foreigners within 6 months from the expiration of the agreement, if the grounds for issuing the return order was fulfilled by irregular stay

\footnotetext{
${ }^{228}$ Interview \#20 with representatives of an IT company, Bulgaria, December 2016, Annex III.

${ }^{229}$ Interview \#18 with representatives of an IT company, Bulgaria, September 2016, Annex III.

${ }^{230}$ Directive (EU) 2016/801 of the European Parliament and of the Council of 11 May 2016 on the conditions of entry and residence of third-country nationals for the purposes of research, studies, training, voluntary service, pupil exchange schemes or educational projects and au pairing [2016] OJ L 132.

${ }^{231}$ If the application is not submitted in person, the applicant is obliged to appear at the relevant province within 7 days of the date of submitting application in line with Article 105 (1) $2 \mathrm{AF}$.

${ }^{232}$ Article 151 (1) 2 AF. Only research institutions covered by the Act on the rules of financing of science of 2010 can apply for approval to sign an agreement with a foreign researcher. For all requirements towards the research organisation, see Article 151 (4) AF.
} 
in Poland. ${ }^{233}$ The rest of the requirements were the same as for the other temporary residence permits - i.e. obligation to have health insurance and the possession of sufficient financial resources. ${ }^{234}$ The permit was valid for a period of up to 3 years.

The Act of 22 February 2019 amending the Act on Foreigners and Certain Other Acts ${ }^{235}$ implemented the new Students' and Researchers' Directive into Polish law. The most significant change brought by this EU law instrument into Polish law was the opportunity for researchers to apply for a temporary residence permit for a period of 9 months thus enabling them to look for work or to start a business in Poland after completing scientific research (Article 186 (1) 7 of the AF). This category of foreigners is also exempted from the requirement to apply for a work permit pursuant to Article 87 (2) 1 of the Act of 20 April 2004 on Promotion of Employment and Labour Market Institutions.

In Bulgaria, the new Students' and Researchers' Directive was transposed in ALMLM with the amendments from 16 March 2018. ${ }^{236}$ In line with Article 246 (1) of the AFRB, researchers are entitled to receive a continuous residence permit in cases where they have obtained a visa under Article 15 (1) and have concluded a contract for the development of a 'scientific research project' with a 'scientific research organisation' that has its seat in Bulgaria and which is entered into the register of scientific research organisations in accordance with the Article 7б (1) 1 of the Act on the Promotion of Research. ${ }^{237}$ In order to be granted a continuous residence permit, researchers need to meet the requirements stipulated by Article 24 (2) of the AFRB, such as having secured accommodation, obligatory health insurance and social insurance, and sufficient living funds for the duration of their stay.

This permit is granted for a period not shorter than 1 year (Article 246 (2) of the AFRB). In the event that the term of development of the scientific research project is less than 1 year, the residence permit is granted for the duration of the project. Foreigners are required to submit a residence permit application first and then register with the Employment Agency through the host research organisation. ${ }^{238}$ Thirdcountry nationals who are admitted as researchers for the purposes of conducting a research project under a contract with a hosting research organisation in Bulgaria are exempt from the requirement to possess a work permit for the duration of their project (Article 36 (1) of the ALMLM). Upon completion of the research project, a

\footnotetext{
${ }^{233}$ Article 151 (1) 1 (c) AF.

${ }^{234}$ Article 151 (1) 1 (a) and (b) AF.

${ }^{235}$ The Act of 22 February 2019 amending the Act on Foreigners and Certain Other Acts/ Ustawa z dnia 22 lutego 2019 r. o zmianie ustawy o cudzoziemcach oraz niektórych innych ustaw (Dziennik Ustaw z 2019 r., poz. 577). The amendment entered into force on 27 April 2019.

${ }^{236}$ SG No. 24/ 16 March 2018 which entered into force on 23 May 2018.

237 Закон за насърчаване на научните изследвания (SG No. 92/ 17October 2003, latest amendment SG No. 77/ 18 September 2018).

${ }^{238}$ The supporting documents that need to be submitted as part of the continuous permit application are stipulated in Articles 14 (1) and 29д (1) of the Implementing Regulation of the AFRB. The supporting documents that need to be submitted for the registration with the Employment Agency are stipulated in Article 33 of the Implementing Regulation of the ALMLM.
} 
third-country national is entitled to seek and take up employment as well as benefit from the services stipulated under the Employment Promotion Act within 9 months after submitting a registration application with the Employment Agency (Article 36 (1) 3 of the ALMLM).

\subsubsection{Students' and Researchers' Directive - Implementation Dynamics}

As already mentioned, at the time of the empirical data collection in the period 2016-2017 as part of this research, neither Poland nor Bulgaria had transposed the new Students' and Researchers' Directive. This did not allow for any examination of the implementation of this instrument through focus groups with researchers or interviews with stakeholders. Data obtained from the administrations in Bulgaria and Poland, however, suggest that the use of the EU acquis concerning researchers, covering both the former Researchers' Directive and the Recast from 2016, is marginal in both countries.

According to the data of the Polish Office for Foreigners, 397 temporary residence permits for researchers have been issued in the past 10 years. ${ }^{239} \mathrm{By}$ comparison, in Bulgaria this number totals 24 for the same period. ${ }^{240}$ Interestingly enough, the data obtained from the Bulgarian Employment Agency show that there were only three foreigners registered as researchers through a host research organisation. ${ }^{241}$ This could mean either that host institutions are violating the requirements of the ALMLM by not registering the researchers with the Agency or that the issued residence permits were based on bilateral measures, as some of the study's research informants pointed out.

One of the interviewed Bulgarian officials shared a general problem concerning foreigners coming to the country on a scientific exchange programme as per Article 15 (2) of the Act on Foreigners. ${ }^{242}$ This article provides for the issuance of a longterm visa with a validity of 1 year, which falls outside the scope of the Researchers' Directive. However, the use of this article as grounds for entry created problems with regard to the lack of legal possibilities to issue a personal number to a foreigner, which was required by the Ministry of Education, other public institutions, as well as private companies such as mobile phone operators. ${ }^{243}$ According to the interviewed official: 'In such cases, after many reservations and making a compromise, we issue a visa under Article 15 (1) of the AFRB and we grant the person a permit for continuous residence, because the lack of personal number of a foreigner

\footnotetext{
${ }^{239}$ Data obtained from the Polish Office of Foreigners in October 2019.

${ }^{240}$ Data obtained from the Ministry of Interior in September 2019 with Decision No. 5364p151461/12 August 2019 of Migration Directorate of the Ministry of Interior.

${ }^{241}$ Information obtained via official request to information under Decision № РД-08-2156 from 12.08.2019 of the general secretary of the Employment Agency.

${ }^{242}$ Interview \#2 with state official, Bulgaria, July 2016, Annex III.

${ }^{243}$ Interview \#2 with state official, Bulgaria, July 2016, Annex III.
} 
does not allow for normal life in Bulgaria'. ${ }^{24}$ It was unclear whether this provision was used only for researchers coming under national measures or whether it also covered cases under the Directive, which would constitute a violation because Member States are only required to issue residence permits. ${ }^{245}$

\subsection{Conclusions}

This chapter aimed at assessing whether the developed instruments provide options for facilitated entry for migrants from the Eastern Partnership countries and Russia, as well as circulation-friendly policies. It demonstrated that Poland facilitates entry for nationals of Eastern Partnership countries and Russia through both national and EU visa policy instruments, as well as on the basis of national mechanisms such as the Oświadczenie procedure and the Karta Polaka, which is in line with the benchmarks of this study. Poland is gradually liberalising access to its labour market based on a wide spectrum of exemptions from work permit applications and the performance of a labour market test regulated through bylaws.

Contrary to Poland, Bulgaria provides quite limited national measures for facilitated entry for the citizens of the Eastern Partnership countries. Currently the only visa facilitation concerns priority visa processing for citizens of Armenia and Moldova entering under the bilateral labour migration agreements concluded with these countries in 2018, and the outsourced Visa Application Centres for nationals of Ukraine and Russia. Citizens of the Eastern Partnership, however, can benefit from the developed EU visa facilitation instruments, visa-free regimes, and other EU legal instruments such as the Blue Card Directive and the Seasonal Workers' Directive whose transposition has been amended recently to provide liberalised access following pressure from business organisations. Furthermore, applicants can make use of the national measures targeting foreigners of Bulgarian origin that provide for facilitated access to the labour market and permanent residence, as well as a fast-track citizenship procedure in case they decide to apply for Bulgarian citizenship on the basis of their Bulgarian ethnic origin.

The migrants interviewed in Poland used both the Karta Polaka and the Oświadczenie procedure as circulation-friendly instruments as part of their changing migrant-led trajectories. In addition, the multiple-entry visa under the Visa Facilitation Agreement with Russia stands out as an EU instrument that has also been useful for circular migration purposes. On the other hand, the restrictive admission procedures in Bulgaria trigger what can be referred to as 'forced circularity', which aims to keep migrants in a temporary position. Foreign workers are supposed to stay in the country for only a limited period of time, until they or their respective

\footnotetext{
${ }^{244}$ Interview \#2 with state official, Bulgaria, July 2016, Annex III.

${ }^{245}$ The Directive allowed for a transition period under Article 18, where Member States were not obliged to issue residence permits. However, this period has since expired. See also Peers (2012), p. 138.
} 
employers train a Bulgarian or another legally-resident foreigner to fill the job in question. Therefore, currently, all categories of migrant workers, except for Blue Card holders and foreigners of Bulgarian origin, need to exit the country for a minimum period in order to obtain new permits or change their status. This policy has also been reflected in the concluded bilateral labour migration agreements and is not considered to be in line with the study's benchmarks because it does not allow for migrant-led trajectories.

Even though it provides for flexible geographic mobility, the Blue Card instrument is not used for circular migration purposes per se. The Blue Card holders wishing to spend time working in their countries of origin use the company's internal 'home office' mechanisms to circulate back and forth. Outside of this practice, however, they are not interested in circulating for work, mainly due to political and economic factors. The other EU instrument considered suitable for promoting circular migration, the EU long-term residence permit, also does not seem to be an attractive tool for circulation for settled migrants in Poland and Bulgaria. The few interviewed migrants with such national or EU permits used them to maintain their transnational links with their country of origin but did not consider this to be workrelated circulation. In the case of Bulgaria, because migrants invest many resources and expend great effort to enter the country and stay there, they perceive voluntary circulation as being too risky and their main goal is to obtain EU long-term or permanent residence.

So far, the Researchers' and the ICTs Directives have had a marginal use in both countries mainly due to the cumbersome and ineffective procedures created as part of their transposition into Polish and Bulgarian law. In addition, apart from the Oświadczenie procedure in Poland and the concluded bilateral agreements in Bulgaria, the rest of the initiatives developed under the auspices of the Mobility Partnerships have not contributed much to the facilitation of entry and re-entry conditions for citizens of the Eastern Partnership countries.

Lastly, the Local Border Traffic agreement with Ukraine cannot be directly used for circular migration related to work, but can lead to the initiation of circular migration because it provides job-seeking opportunities. Nevertheless, in order to gain insights into its implementation, one needs to conduct targeted field research in the border region, which is a matter that falls outside the scope of this research.

The main problems identified in both countries concerned the protection of migrants' rights. In Poland, for example, implementation of the Oświadczenie procedure in many instances involved the use of fake declarations that enabled migrants to enter Poland to look for a job and obtain a new Oświadczenie (declaration) stating the real employment or find other ways to 'legalise their stay'. Seasonal workers, however, used the Oświadczenie procedure as means of gaining entry into Poland, but in most cases they did not seek to regularise their work by signing a contract to this effect. These problems naturally placed migrant workers in a vulnerable position that could lead to abuse by their employers. Poland has addressed these issues and reformed the Oświadczenie procedure in 2018, inter alia, by providing a legal basis for refusing to register a declaration and the possibility to conduct additional 
verification. However, the country now needs to concentrate more efforts on the enforcement of rights-based circulation and protection of migrants' rights.

On the other hand, the analysis of Bulgarian migration law and the empirical data collected demonstrated that the restrictive entry and re-entry conditions that Bulgaria has established on the basis of both national and, to some extent, the implemented EU law, in general, lead to 'forced circulation'. Due to the involuntary circulation mechanisms for change of visas and statuses, the migrants' main desire is to achieve security of residence after 5 years and no longer circulate between their country of origin and their country of destination. Seasonal workers are probably the only exception in this regard. Thus, this study suggests that the Bulgarian circular migration approach resembles the guest worker model and is not conducive to a migrantled trajectory. Furthermore, it has created a breeding ground for abuses of migrants' rights and can lead to exploitation as it forces migrants to circumvent the applicable legislation, leads to dependency on employers, and leaves wide discretion to the administration to take decisions about migrants' lives.

This notwithstanding, EU law is the only channel that could lead to the facilitation of rights-based circular migration in Bulgaria; the visa-liberalisation regimes and the EU's desire to turn the Blue Card into a more effective instrument are expected to lead to greater opportunities for facilitated entry and re-entry. Furthermore, as a result of the infringement procedures against Bulgaria, as well as the growing demand for foreign labour and the lobbying carried out by business organisations, the incorrect and cumbersome national transposition measures are slowly being brought more in line with their effet utile and access to the Bulgarian market has been liberalised for certain categories of workers. On the other hand, Poland transposed the EU labour migration legislation in a rather flexible manner, for instance allowing applications and change of status to be effected both from outside and within the country. Despite the great delay in the transposition of the Seasonal Workers' Directive, the country created procedures adapted to its national labour market needs.

\section{References}

Bieniecki, M. and M. Pawlak (2009) Strategie przetrwania. Adaptacja ukraińskich migrantów zarobkowych do polskiej rzeczywistości instytucjonalnej. Instytut Spraw Publicznych, Warsaw.

Council of Ministers (2015) National Strategy in the field of Migration, Asylum and Integration (2015-2020), adopted with Council of Ministers Decision No. 437/12 June 2015, Sofia.

Dnevnik (2017) Hotels and restaurants camouflage the hiring of foreigners with training contracts. http://www.dnevnik.bg/biznes/turizam/2017/03/10/2932528_hoteli_i_restoranti_zamaskirat_ naemaneto_na_chujdenci/ Accessed 11 October 2017.

European Commission (2019a) Report on Directive 2011/98/EU of the European Parliament and of the Council of 13 December 2011 on a single application procedure for a single permit for third-country nationals to reside and work in the territory of a Member State and on a common set of rights for third-country workers legally residing in a Member State, COM (2019) 160 final, 29 March 2019, Brussels. 
European Commission (2019b) Report on the implementation of Directive 2003/109/EC concerning the status of third-country nationals who are long-term residents, COM (2019) 161 final, Brussels, 29 March 2019, Brussels.

European Migration Network (2012) Visa policy as migration channel in Poland. National Report. Prepared by the National Contact Point to the European Migration Network, Warsaw.

European Migration Network (2015) Changes in immigration status and purpose of stay: an overview of Bulgarian approaches. Report on Bulgaria.

European Migration Network (2018) Labour market integration of third-country nationals in EU Member States. Report on Bulgaria. https://ec.europa.eu/home-affairs/sites/homeaffairs/ files/03a_bulgaria_labour_market_integration_final_en.pdf Accessed 12 December 2019.

Górny, A., P. Kaczmarczyk, M. Szulecka, M. Bitner, M. Okólski, U. Siedlecka and A. Stefańczyk (2018) Imigranci w Polsce w kontekście uproszczonej procedury zatrudniania cudzoziemców. Warszawa: Uniwersytet Warszawski.

Fomina, J. (2011) Local border traffic agreement for the Kaliningrad region: a success story of the Polish presidency and a trust-building exercise for Poland and Russia. Policy Brief. Warsaw: Stefan Batory Foundation.

International Organization for Migration Mission to Georgia (2017) Temporary Labour Migration of Georgian Workers to Poland and Estonia. http://iom.ge/1/labour-migration Accessed 30 April 2017.

Kindler, M., A. Kordasiewicz and M. Szulecka (2016) Care needs and migration for domestic work: Ukraine-Poland. Global Action Programme on Migrant Domestic Workers and their Families. An ILO/UE project. Geneva: International Labour Office.

Kozak, I., M. Tota and B. Wojcik (2014) Long-term Residence of Foreigners in Poland in the Light of Act on Foreigners of 12 December 2013. In T. Sieniow (ed.), Prawo I Polityka Migracyjna II. Lublin: Rule of Law Institute Foundation.

Lessenski, M. (2009) The EU New Member States as Agenda Setters in the Enlarged European Union. Country Report: Bulgaria. European Policies Initiative. Open Society Institute, Sofia.

Mazowieckie For Foreigners (2019) EU Blue Card 2019. https://mazowieckie.pl/en/for-foreigners-1/residence/temporary-residence-pe/eu-blue-card/446, What-fees-do-I-have-to-pay.html Accessed 15 December 2019.

Ministry of Foreign Affairs (2018) Visa for Bulgaria. https://www.mfa.bg/en/services-travel/consular-services/travel-bulgaria/visa-bulgaria Accessed 12 September 2019.

Migrantinfo.pl (2018) Local Border Traffic. http://www.migrant.info.pl/Local_border_traffic.html Accessed 27 April 2019.

National Assembly of the Republic of Bulgaria (2015) http://www.parliament.bg/pub/ cW/20150619090636Volen-VIZI.pdf Accessed 26 November 2017.

National Contact Point to the European Migration Network (2013) Poland abolished long-term visa fees for Moldovan citizens. https://emn.gov.pl/ese/news/10543,Poland-abolished-longterm-visa-fees-for-Moldovan-citizens.html Accessed 25 April 2017.

National Council on Migration and Integration (2019) Report on the 2018 Action Plan for the Implementation of the 2015-2020 National Strategy in the field of Migration, Asylum and Integration adopted with Council of Ministers Protocol No. 24.3 of 12 June 2019, Sofia.

OECD (2013) International Immigration Outlook 2013: Poland. Paris: OECD Publishing.

OECD (2018) International Immigration Outlook 2018: Poland. Paris: OECD Publishing.

Offnews (2017) The procedure for recruitement of seasonal workers have been eased. https:// offnews.bg/turizam/ulesniha-protcedurata-za-naemane-na-sezonni-rabotnitci-ot-chuzhbina-658341.html Accessed 11 October 2017.

Pawlak, M. and I. Lashchuk. (forthcoming). Entry to the labour market, not to the state - migrant workers' perspectives in Poland. Report commissioned by the Friedrich Ebert Foundation.

Peers, S. (2012) Admission of Researchers. In Peers, S., E. Guild and J. Tomkin (eds). EU Immigration and Asylum Law (Text and Commentary): Second Revised Edition. Volume 1: Visas and Border Controls. Leiden: Martinus Nijhoff Publishers, pp. 129-164. 
Peers, S. (2016) EU Justice and Home Affairs Law. Volume I: EU Immigration and Asylum Law. Fourth Edition. Oxford: Oxford University Press.

Radio Poland (2016) Local border traffic between Poland and Russia to remain suspended, 15 September 2016. http://www.thenews.pl/1/10/Artykul/271016,Local-border-traffic-betweenPoland-and-Russia-to-remain-suspended Accessed 15 May 2017.

Statistics Poland (2018) Demographic Yearbook of Poland, Warsaw. https://stat.gov.pl/files/ gfx/portalinformacyjny/pl/defaultaktualnosci/5515/3/12/1/rocznik_demograficzny_2018. pdf\#page=456 Accessed 1 December 2019.

Unterschütz, J. (2016) National Report on Implementation of EU Migration Directives in Poland. In R. Blanpain, F. Hendrickx and P. Olsson (ed.), National Effects of the Implementation of EU Directives on Labour Migration from Third Countries. Alphen aan den Rijn: Wolters Kluwer, pp. 161-192.

Vankova, Z. (2017) Implementing the EU's Circular Migration Approach: Legal and Migrant Perspectives on Entry and Re-Entry Conditions in Bulgaria and Poland. Robert Schuman Centre for Advanced Studies Research Paper No. RSCAS 2017/34. Florence: European University Institute.

Vankova, Z. and B. Ivanova (forthcoming) Temporary home or final destination? Migrant workers' perspectives in Bulgaria. Report commissioned by the Friedrich Ebert Foundation.

Wasilewska, O. (2008) Analysis of the visa policies of the Visegrad countries: Relative openness. Polish visa policy towards Belarus, Moldova, Russia and Ukraine. Warsaw: Stefan Batory Foundation.

Znadniemna (2018) Białoruś: Do wprowadzenia małego ruchu granicznego z Polską brakuje przejść granicznych. http://znadniemna.pl/4487/bialorus-wprowadzenia-malego-ruchu-granicznego-polska-brakuje-przejsc-granicznych/ Accessed 1 December 2019.

Open Access This chapter is licensed under the terms of the Creative Commons Attribution 4.0 International License (http://creativecommons.org/licenses/by/4.0/), which permits use, sharing, adaptation, distribution and reproduction in any medium or format, as long as you give appropriate credit to the original author(s) and the source, provide a link to the Creative Commons license and indicate if changes were made.

The images or other third party material in this chapter are included in the chapter's Creative Commons license, unless indicated otherwise in a credit line to the material. If material is not included in the chapter's Creative Commons license and your intended use is not permitted by statutory regulation or exceeds the permitted use, you will need to obtain permission directly from the copyright holder. 